\title{
Sex differences in mechanisms of cardiac excitation-contraction coupling
}

\author{
Randi J. Parks • Susan E. Howlett
}

Received: 8 January 2013 /Revised: 29 January 2013 / Accepted: 30 January 2013 / Published online: 17 February 2013

(C) The Author(s) 2013. This article is published with open access at Springerlink.com

\begin{abstract}
The incidence and expression of cardiovascular diseases differs between the sexes. This is not surprising, as cardiac physiology differs between men and women. Clinical and basic science investigations have shown important sex differences in cardiac structure and function. The pervasiveness of sex differences suggests that such differences must be fundamental, likely operating at a cellular level. Indeed, studies have shown that isolated ventricular myocytes from female animals have smaller and slower contractions and underlying calcium transients compared to males. Recent evidence suggests that this arises from sex differences in components of the cardiac excitation-contraction coupling pathway, the sequence of events linking myocyte depolarization to calcium release from the sarcoplasmic reticulum and subsequent contraction. The concept that sex hormones may regulate intracellular calcium at the level of the cardiomyocyte is important, as levels of these hormones decline in both men and women as the incidence of cardiovascular disease rises. This review focuses on the impact of sex on cardiac contraction, in particular at the cellular level, and highlights specific components of the excitation-contraction coupling pathway that differ between the sexes. Understanding sex hormone regulation of calcium homeostasis in the heart may reveal new avenues for therapeutic strategies to treat cardiac dysfunction and cardiovascular diseases.
\end{abstract}

This article is published as part of the Special Issue on "Sex differences in health and disease: brain and heart connections".

\section{R. J. Parks · S. E. Howlett $(\bowtie)$}

Department of Pharmacology, Dalhousie University,

Sir Charles Tupper Medical Building, 5850 College Street,

PO Box 15000, Halifax, NS B3H 4R2, Canada

e-mail: Susan.Howlett@dal.ca

\section{S. E. Howlett}

Department of Medicine (Geriatric Medicine), Dalhousie University, 5850 College Street, PO Box 15000, Halifax, NS B3H 4R2, Canada
Keywords Calcium transients · Calcium sparks · Gain · Oestrogen · Gender · Ovariectomy

\section{Introduction}

Clinical studies have identified striking differences between men and women in the incidence and expression of many different cardiovascular diseases. This should not be surprising; there are also sex differences in the normal structure and physiology of the heart. Although information is limited, there is evidence that myocardial electrical and contractile function differ between the sexes. Studies that have included both males and females have distinguished important differences in cardiac contractile function, even at the level of the individual cardiomyocyte. Additionally, cardiomyocytes possess receptors for major sex steroid hormones, and these hormones are thought to regulate myocardial function. This has led to considerable interest in identifying the cellular mechanisms responsible for sex differences in myocardial function. Indeed, recent studies have identified intriguing differences at several different levels of the excitation-contraction (EC) coupling pathway, which is responsible for the contraction of individual cardiomyocytes.

This review highlights our knowledge of the impact of sex on cardiac contraction and examines specific components of the EC coupling pathway that differ between males and females. Acute and chronic effects of sex hormones on components of this pathway are also considered. Current controversies are discussed, and important questions are raised for future research. Further understanding of the cellular mechanisms responsible for sex differences in myocardial function can begin to reveal why varying pathologies arise in males and females. This could lead to a better appreciation of the role of sex hormones in the regulation of cardiac function and to the development of more appropriate sex-specific therapies for cardiovascular diseases. 


\section{Sex differences in cardiac function}

Important differences have been described in the incidence and susceptibility to cardiovascular disease in men and women $[30,84,90]$. For example, women typically experience coronary artery disease and myocardial infarction about 10 years later than men [87]. Hypertrophic and dilated cardiomyopathies both occur more frequently in men than in women, whereas Tako-Tsubo cardiomyopathy is seen almost exclusively in women [87]. Men also tend to develop heart failure with impaired systolic function as they age, while older women have a higher incidence of heart failure with preserved ejection fraction [87].

These differences in cardiac pathophysiology may originate, at least in part, from sex differences in the structure and function of the heart. In humans, echocardiographic studies have revealed that left ventricular (LV) mass is significantly smaller in women than in men [31,32]. Echocardiography has also shown that females have reduced LV end-diastolic dimension [11, 111]. In addition, women have higher resting heart rates and longer corrected QT intervals than men [52, 125]. Radiographic studies using ventriculography have demonstrated that women possess a higher ejection fraction at rest than men [11]. Even so, men respond to exercise with a greater increase in ejection fraction than do women $[52,76]$. This decrease in the ability of the female heart to respond to increased demand has been shown to be independent of sex differences in myocardial regulation by the sinus node or by autonomic tone [15]. This raises the question of whether individual cardiomyocytes from female hearts may have limited ability to augment contractile function, in particular in response to stimuli that increase demand.

Studies in animal models have provided additional evidence that cardiac contractile function differs between the sexes. In a working heart model, female rats have a smaller ejection fraction and exhibit less fractional shortening in comparison to age-matched males [95]. Studies in cardiac muscle strips from rats found similar results, in that responses were smaller and slower in females in comparison to males, particularly in conditions of higher demand such as rapid pacing rates [27, 65, 83]. By contrast, in vivo studies with Doppler echocardiography have reported no sex differences in functional parameters such as ejection fraction and fractional shortening in CD1 mice [104]. However, these in vivo results could be affected by the use of anaesthetics, which can alter cardiac function by decreasing heart rate and may abolish any sex differences that are present. Furthermore, indices such as ejection fraction and fractional shortening depend on LV loading status, which may differ between males and females. This may also mask sex differences in cardiac function.

Most experimental studies in hearts and cardiac muscle preparations have revealed lower myocardial contractile function in females. Sex differences in cardiac contractile function are likely to arise, at least in part, through differences in the ability of individual cardiomyocytes to contract. As cardiac contractions result from a transient rise in intracellular $\mathrm{Ca}^{2+}$ levels in cardiomyocytes [4, 35], they may reflect underlying sex differences in intracellular $\mathrm{Ca}^{2+}$ handling at the cellular level. The sequence of events that link cardiac excitation to $\mathrm{Ca}^{2+}$ release from the sarcoplasmic reticulum (SR) and contraction is known as EC coupling. This process will be briefly reviewed.

\section{Cardiac excitation-contraction coupling}

In cardiomyocytes, $\mathrm{Ca}^{2+}$ levels are tightly regulated via the EC coupling pathway. This pathway converts an electrical stimulus from the sinoatrial node into a mechanical contraction, causing the heart to eject blood. In ventricular myocytes, EC coupling is initiated when the action potential propagated along the cell membrane causes cellular depolarization, which activates voltage-sensitive L-type $\mathrm{Ca}^{2+}$ channels and results in an inward $\mathrm{Ca}^{2+}$ current [4]. L-type $\mathrm{Ca}^{2+}$ channels located within invaginations in the membrane are closely associated with $\mathrm{Ca}^{2+}$ release channels located on the SR [97]. These SR $\mathrm{Ca}^{2+}$ release channels are also known as ryanodine receptors (RyRs). $\mathrm{Ca}^{2+}$ influx triggers $\mathrm{SR} \mathrm{Ca}{ }^{2+}$ release by binding to RyRs, resulting in their opening and the subsequent release of SR $\mathrm{Ca}^{2+}$, which gives rise to $\mathrm{Ca}^{2+}$ transients [37, 38].

The amount of $\mathrm{Ca}^{2+}$ released from the SR is much larger than the trigger $\mathrm{Ca}^{2+}$ that enters the cell, a phenomenon known as $\mathrm{Ca}^{2+}$-induced $\mathrm{Ca}^{2+}$ release. The degree of amplification of $\mathrm{Ca}^{2+}$ influx to the resulting amount of $\mathrm{Ca}^{2+}$ released from the SR can be quantified by measuring a parameter known as EC coupling "gain". Experimentally, gain is calculated as the ratio of the amount of SR Ca ${ }^{2+}$ released $\left(\mathrm{Ca}^{2+}\right.$ transient $)$ per unit of $\mathrm{Ca}^{2+}$ current [6]. Factors such as elevated SR $\mathrm{Ca}^{2+}$ load, a decrease in temperature or $\beta$-adrenergic stimulation have been shown to increase the gain of cardiac EC coupling [42, 100, 112]. By contrast, H-89, which inhibits protein kinase A (PKA), reduces the gain of EC coupling [81]. Therefore, modulation of EC coupling gain can potentially augment or inhibit SR $\mathrm{Ca}^{2+}$ release and contraction independently of changes in $\mathrm{Ca}^{2+}$ influx.

The rise in intracellular $\mathrm{Ca}^{2+}$ concentration caused by the $\mathrm{Ca}^{2+}$ transients allows $\mathrm{Ca}^{2+}$ to bind to the myofilaments, specifically troponin $\mathrm{C}$, ultimately resulting in contraction of the myocyte [4,35]. Relaxation occurs when the majority of $\mathrm{Ca}^{2+}$ is sequestered into the $\mathrm{SR}$ via the sarco/endoplasmic reticulum $\mathrm{Ca}^{2+}$-ATPase (SERCA), while a much smaller amount of $\mathrm{Ca}^{2+}$ is removed from the cell predominantly by the $\mathrm{Na}^{+} / \mathrm{Ca}^{2+}$ exchanger (NCX) [89]. $\mathrm{Ca}^{2+}$ reuptake in the $\mathrm{SR}$ is regulated by phospholamban (PLB), which inhibits SERCA. It is this tightly regulated sequence of events that 
mediates the synchronous contraction of cardiomyocytes, and thus must be considered when evaluating cardiac contractile function in males and females.

$\mathrm{SR} \mathrm{Ca}^{2+}$ is released in the form of discrete, subcellular $\mathrm{Ca}^{2+}$ release units called $\mathrm{Ca}^{2+}$ sparks. $\mathrm{Ca}^{2+}$ sparks are thought to result from the activation of a cluster of 6 to 20 RyR channels complexed with an L-type $\mathrm{Ca}^{2+}$ channel [20, 62], and many of these release units will fuse to form $\mathrm{Ca}^{2+}$ transients [49]. Spontaneous $\mathrm{Ca}^{2+}$ sparks can also occur in quiescent myocytes in the absence of L-type $\mathrm{Ca}^{2+}$ channel openings $[20,41]$. The frequency and amplitude of spontaneous $\mathrm{Ca}^{2+}$ sparks is increased with increasing $\mathrm{SR} \mathrm{Ca}^{2+}$ load [94]. In fact, spontaneous $\mathrm{Ca}^{2+}$ sparks are thought to represent a leak pathway to limit SR $\mathrm{Ca}^{2+}$ content under conditions of $\mathrm{SR} \mathrm{Ca}^{2+}$ overload [94]. Changes in the properties of individual $\mathrm{Ca}^{2+}$ sparks, such as their size and frequency, can affect $\mathrm{Ca}^{2+}$ transient amplitudes, as well as SR $\mathrm{Ca}^{2+}$ content. Comparison of these unitary $\mathrm{Ca}^{2+}$ release events, between males and females for example, can reveal unique $\mathrm{Ca}^{2+}$ handling characteristics of individual cardiomyocytes.

One important pathway in the regulation of EC coupling in cardiomyocytes is the cyclic adenosine monophosphate (cAMP)/PKA pathway. Upon activation of the $\beta$-adrenergic receptor, adenylyl cyclase will increase the conversion of ATP into cAMP, which will activate PKA. PKA phosphorylates various components of the EC coupling pathway and causes an increase in inotropy and lusitropy [5]. L-type $\mathrm{Ca}^{2+}$ channel phosphorylation will increase the size of the $\mathrm{Ca}^{2+}$ current [59], thus causing a larger $\mathrm{Ca}^{2+}$-induced $\mathrm{Ca}^{2+}$ release from the SR [5]. Phosphorylation of PLB alleviates its inhibition on SERCA activity and increases SR $\mathrm{Ca}^{2+}$ uptake, resulting in a faster $\mathrm{Ca}^{2+}$ transient decay [67]. Phosphorylation of troponin I causes faster relaxation by promoting dissociation of $\mathrm{Ca}^{2+}$ from the myofilaments [127]. A second protein kinase implicated in the regulation of cardiac contractile function is the $\mathrm{Ca}^{2+}$-calmodulin-dependent kinase II (CaMKII). CaMKII also phosphorylates various components of the EC coupling pathway to cause an increase in lusitropy and inotropy, though to a lesser extent than PKA $[5,17,126]$. As PKA and CaMKII increase contraction size by increasing the size of the $\mathrm{Ca}^{2+}$ transients, these pathways are important to consider when examining contractile function in individual myocytes. Sex differences in either of these kinases could contribute to differences in $\mathrm{SR} \mathrm{Ca}^{2+}$ release and contraction in cardiomyocytes from males and females.

Contractile function in isolated ventricular myocytes from males and females

Over the past decade, a number of studies have investigated whether sex differences in the ability of individual cardiomyocytes to contract contribute to the differences in cardiac contractile function reported in studies of intact heart and isolated cardiac muscle preparations. Some studies in field stimulated rat ventricular myocytes have reported either no difference in peak contraction between males and females [113] or an increase in contraction in cells from females [96], although this latter study found that sex differences were abolished when external $\mathrm{Ca}^{2+}$ levels were increased. However, as shown in Table 1, these studies were performed at room temperature, rather than at $37{ }^{\circ} \mathrm{C}$, and myocytes were paced at stimulation frequencies between 0.5 and $0.8 \mathrm{~Hz}$, which is far below the physiological heart rate in rats [98]. Other studies have used physiological or close to physiological stimulation frequencies (e.g. 1 to $4 \mathrm{~Hz}$ ) to investigate sex differences in cardiac contractile function at the cellular level. Figure 1a depicts representative examples of contractions, $\mathrm{Ca}^{2+}$ transients and $\mathrm{Ca}^{2+}$ currents recorded simultaneously in voltage clamp experiments by Farrell et al. [40]. Mean data from this study shows that peak contractions are significantly smaller in ventricular myocytes from female rat hearts in comparison to cells from males (Fig. 1b). Additional field stimulation and voltage clamp experiments have revealed that cells from young adult female rats have smaller and slower contractions in comparison to age-matched males [29, 40,55]. Whether this applies to all species is not clear, as one study performed in mice reported no sex difference in myocyte contraction size [46]. Studies examining contraction and relaxation of isolated ventricular myocytes from male and female rats are summarized in Table 1. Taken together, most studies show that sex differences in cardiac contraction are present at the cellular level, in particular if myocytes are paced at physiological rates. As cardiomyocyte contraction is proportional to pacing frequency in cells from rodents [68], it is perhaps not surprising that sex differences in cardiac contractile function are more apparent at rapid pacing rates. Further, as discussed earlier, studies in intact hearts, papillary muscles and ventricular trabeculae found that sex differences were more prominent at rapid stimulation rates. These results support the conclusion that sex differences in cardiac contractility are due, at least in part, to differences in the ability of individual cardiomyocytes to contract.

Sex differences in the contraction size of individual cardiomyocytes could arise from differences in the contractile machinery in cells from males and females. Therefore, the abundance and properties of myofilament proteins have been compared in male and female hearts. Female rat ventricles have been reported to possess higher levels of both $\alpha$ and $\beta$-myosin heavy chain (MHC) and of sarcomeric actin mRNA in comparison to males [92]. However, there is no sex difference in the ratio of $\alpha$ - to $\beta$-MHC [92]. Even so, the possibility remains that there are sex differences in the rate of translation or in post-translational modifications of MHC proteins, and this could be evaluated with newer experimental approaches. 
Table 1 Contractile function in isolated ventricular myocytes from female rats in relation to responses in cells from males

\begin{tabular}{|c|c|c|c|c|c|}
\hline Functional change & Model & Frequency $(\mathrm{Hz})$ & {$\left[\mathrm{Ca}^{2+}\right](\mathrm{mM})$} & Temperature $\left({ }^{\circ} \mathrm{C}\right)$ & References \\
\hline $\begin{array}{l}\downarrow \text { Shortening } \\
\leftrightarrow \text { Relaxation }\end{array}$ & Rats & 2 & 1 & 37 & {$[40]$} \\
\hline $\begin{array}{l}\downarrow \text { Shortening } \\
\leftrightarrow \text { Relaxation }\end{array}$ & Rats & 2,4 & 1 & 37 & {$[55]$} \\
\hline $\begin{array}{l}\downarrow \text { Shortening } \\
\text { Slower relaxation }\end{array}$ & Rats & 1 & $0.5-2$ & 25 & [29] \\
\hline $\begin{array}{l}\uparrow \text { Shortening } \\
\leftrightarrow \text { Relaxation }\end{array}$ & Rats & 0.5 & 1.5 & Room temperature & [96] \\
\hline $\begin{array}{l}\leftrightarrow \text { Shortening } \\
\text { Slower relaxation }\end{array}$ & Rats & 0.5 & 3.5 & Room temperature & {$[96]$} \\
\hline$\leftrightarrow$ Shortening & Rats & 0.8 & 1 & - & [113] \\
\hline
\end{tabular}

To determine whether there were functional differences in myofilaments from male and female hearts, Petre et al. [83] compared the $\mathrm{Ca}^{2+}$ sensitivity of myofilaments in skinned ventricular trabeculae from cats of both sexes. They compared maximal force in response to increasing concentrations of $\mathrm{Ca}^{2+}$ and found no sex difference in either the maximal force generated or in the concentration of $\mathrm{Ca}^{2+}$ required to produce $50 \%$ of maximal force $\left(\mathrm{EC}_{50}\right.$ values). Similarly, Schwertz et al. [96] found that the maximal developed force did not differ in skinned muscle fibres from male and female rats. However, myofibrillar ATPase activity was higher in females at any given $\mathrm{Ca}^{2+}$ concentration, which suggests that contractile proteins in female hearts may have greater $\mathrm{Ca}^{2+}$ sensitivity when compared to males [96]. Therefore, it is possible that the contractile machinery within female rat hearts is actually more sensitive to $\mathrm{Ca}^{2+}$, and thus responds to lower intracellular $\mathrm{Ca}^{2+}$ concentrations than males. Certainly, there is no evidence that reduced myofilament responsiveness to $\mathrm{Ca}^{2+}$ explains the smaller contractions characteristic of myocytes from female hearts. Further research is required to confirm this finding, and to determine whether this is true in other animal models, as well as in humans.

Sex differences in $\mathrm{Ca}^{2+}$ transients in isolated ventricular myocytes

The amplitude of cardiac contraction depends not only on the myofilaments but also on the magnitude of the rise in intracellular $\mathrm{Ca}^{2+}[5]$. Thus, the smaller contractions characteristic of cardiomyocytes from female animals may arise from sex differences in the size of the underlying $\mathrm{Ca}^{2+}$ transients. Figure 1a (top panel) depicts representative $\mathrm{Ca}^{2+}$ transients recorded in voltage clamp experiments from myocytes from young adult male and female rats [40]. As shown in this figure and in the mean data in Fig. 1c, peak $\mathrm{Ca}^{2+}$ transients are larger in cardiomyocytes from male hearts in comparison to female hearts. In fact, many studies using either field stimulation or voltage clamp techniques have determined that ventricular myocytes from female rats have smaller $\mathrm{Ca}^{2+}$ transient amplitudes in comparison to cells from males [29, 40, 65, 114]. By contrast, other investigations have reported no difference in $\mathrm{Ca}^{2+}$ transient amplitudes between the sexes in both mouse and rat models $[46,55,124]$. Differences in pacing frequency, temperature and/or species are known to affect intracellular $\mathrm{Ca}^{2+}$ handling [33, 86, 100], and variations in these parameters between studies may help explain these divergent results. Additional factors such as diastolic $\mathrm{Ca}^{2+}$ levels may also be important, as discussed below.

There is growing experimental evidence that contractions are substantially smaller in ventricular myocytes from females than males, in particular when cells are paced at rapid rates. However, the corresponding changes in peak $\mathrm{Ca}^{2+}$ transients are less dramatic, and some studies even report no sex difference in $\mathrm{Ca}^{2+}$ transient amplitudes [46, $55,124]$. It is important to note that the magnitude of cardiac contractions depends not only on the peak $\mathrm{Ca}^{2+}$ transients but also on the level of resting (diastolic) $\mathrm{Ca}^{2+}$ in the cell [4, 99]. For the same amount of activating $\mathrm{Ca}^{2+}$, higher levels of diastolic $\mathrm{Ca}^{2+}$ result in larger contractions [4, 99]. Interestingly, diastolic $\mathrm{Ca}^{2+}$ levels are significantly lower in cardiomyocytes from female rats when compared to male rats $[40,55]$, although no sex differences are seen in murine myocytes [46]. Additional experiments that explore sex differences in cardiomyocytes exposed to varying diastolic $\mathrm{Ca}^{2+}$ levels could determine if lower diastolic $\mathrm{Ca}^{2+}$ levels are contributing to smaller contractions in females.

It is well established that $\mathrm{Ca}^{2+}$ transients in isolated cardiomyocytes from female rats have slower decay rates when compared to males [29, 65, 114]. A reduction in the rate of $\mathrm{Ca}^{2+}$ transient decay suggests that the rate of $\mathrm{Ca}^{2+}$ reuptake into the $\mathrm{SR}$ must be slower in myocytes from females. To investigate this possibility, expression levels of the major SR $\mathrm{Ca}^{2+}$ ATPase cardiac isoform, SERCA2a, have been compared in ventricles from male and female rats. No differences in either SERCA2a protein or mRNA levels in the ventricles of male and female rats have been 
Fig. 1 Mechanisms of cardiac EC coupling differ between the sexes. a Sample recordings of $\mathrm{Ca}^{2+}$ transients (top), contractions (middle) and $\mathrm{Ca}^{2+}$ current (bottom) in ventricular myocytes from 3-month-old male and female rats.

Responses were simultaneously activated by a voltage clamp test step from -40 to $0 \mathrm{mV}$. b, c Contractions and $\mathrm{Ca}^{2+}$ transients were significantly smaller in myocytes from females when compared to males. d SR $\mathrm{Ca}^{2+}$ content, evaluated by the rapid application of $10 \mathrm{mM}$ caffeine, was similar in the two groups. e, f $^{2+}$ spark frequency did not differ between the sexes, but $\mathrm{Ca}^{2+}$ spark amplitudes were smaller in cells from females when compared to males. $\mathbf{g}$ Peak $\mathrm{Ca}^{2+}$ currents were similar in myocytes from males and females. $\mathbf{h}$ The gain of EC coupling (SR Ca ${ }^{2+}$ release per unit $\mathrm{Ca}^{2+}$ current) was much lower in cells from females compared to males. Reprinted from Farrell et al. [40] with permission
A
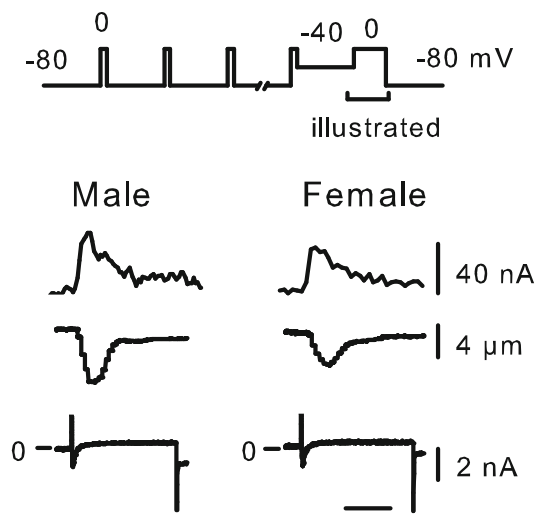

$100 \mathrm{msec}$

C

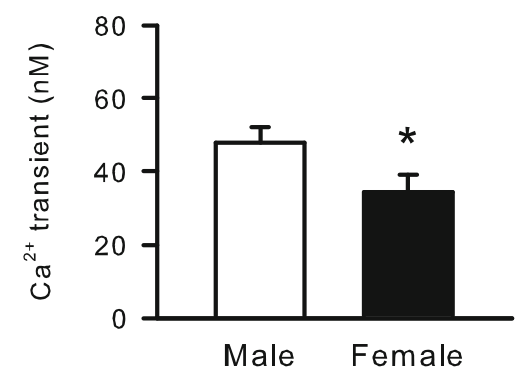

E

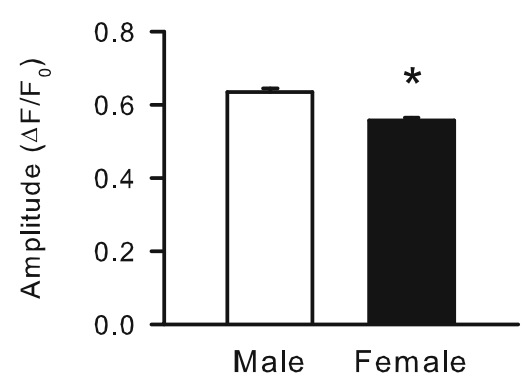

G

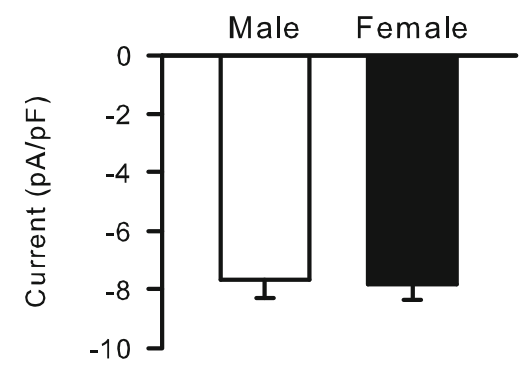

B
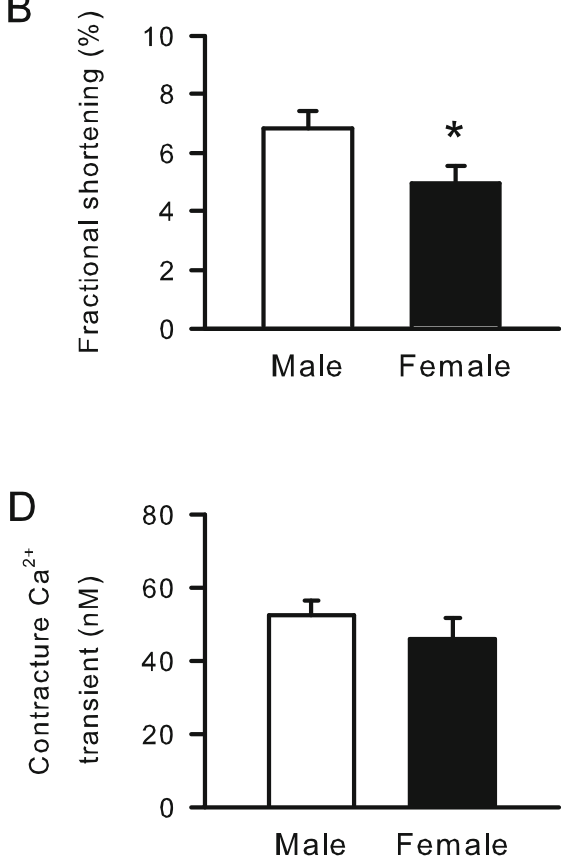

F

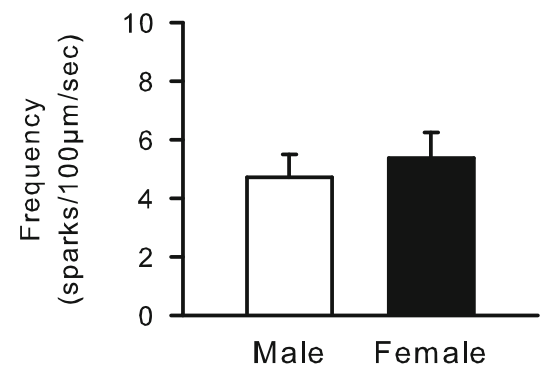

$\mathrm{H}$

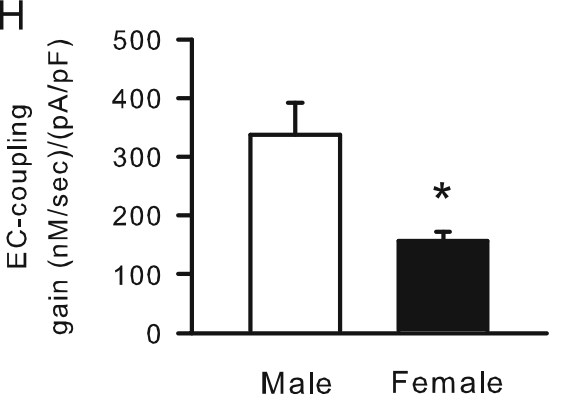

observed [19, 23, 106]. PLB, the intrinsic regulator of SERCA, was also evaluated in hearts from male and female rats. Similar levels of PLB protein and mRNA expression were found in the ventricles of both males and females [19, $23,106]$. Therefore, differences in the rate of decay of the $\mathrm{Ca}^{2+}$ transients are not due to alterations in SERCA2a or PLB protein levels. Future work should determine whether post-translational modifications that alter the activity of SERCA2a or PLB differ between the sexes.
One area that requires further investigation is differences in the cAMP/PKA pathway in cardiomyocytes from males and females. Activation of this pathway plays an important role in increasing SR $\mathrm{Ca}^{2+}$ release and contraction size. Thus, in theory, sex differences in cAMP levels, PKA activity or other components of this pathway could contribute to the observed sex differences in components of cardiac EC coupling. For example, phosphorylation of PLB via PKA is known to accelerate relaxation of ventricular myocytes [67]. 
Reduced levels of phosphorylated PLB could diminish SERCA2a activity and account for the slower rates of $\mathrm{Ca}^{2+}$ transient decay characteristic of ventricular myocytes from female hearts in comparison to males. Similarly, a decrease in PLB phosphorylation by CaMKII could account for the slower rate of decay of $\mathrm{Ca}^{2+}$ transients in females. Further investigation of these pathways in cardiomyocytes from male and female animals may be helpful in understanding the cellular basis for sex differences in cardiac contractile function.

$\mathrm{SR} \mathrm{Ca}^{2+}$ handling in cardiomyocytes from males and females

The magnitude of cardiac contractions and underlying $\mathrm{Ca}^{2+}$ transients depends upon SR $\mathrm{Ca}^{2+}$ content [6]. If cells from female hearts have lower SR $\mathrm{Ca}^{2+}$ content than males, then this could explain why less $\mathrm{Ca}^{2+}$ is released upon depolarization. Therefore, several studies have evaluated the possibility that the amount of SR $\mathrm{Ca}^{2+}$ available for release differs between the sexes. These studies have measured $\mathrm{SR} \mathrm{Ca}^{2+}$ content by rapidly applying $10-20 \mathrm{mM}$ caffeine to cardiomyocytes. Figure 1d shows mean results obtained by Farrell et al. [40]. Mean peak caffeine-induced $\mathrm{Ca}^{2+}$ transients were similar in cardiomyocytes from male and female rats. Other studies in rats have shown that $\mathrm{SR} \mathrm{Ca}^{2+}$ stores are similar in cardiomyocytes from males and females [19, 29, $40,55,124]$. By contrast, one study in guinea pig ventricular myocytes showed that $\mathrm{SR} \mathrm{Ca}^{2+}$ content was, in fact, higher in myocytes from females when compared to cells from agematched males [73]. Therefore, there is considerable evidence that $\mathrm{SR} \mathrm{Ca}^{2+}$ content is either similar in cardiomyocytes from males and females or is actually higher in myocytes from female animals, depending upon the species examined. These findings demonstrate that lower $\mathrm{SR} \mathrm{Ca}^{2+}$ content is unlikely to be responsible for smaller $\mathrm{Ca}^{2+}$ transients that are observed in myocytes from female animals.

To determine whether differences in the abundance of the major SR $\mathrm{Ca}^{2+}$ release channel (RyR2) could account for differences in $\mathrm{SR} \mathrm{Ca}^{2+}$ release between the sexes, several studies have measured RyR2 expression levels in rat ventricles. Interestingly, RyR2 protein and mRNA levels are significantly higher in females when compared to males [23, 124]. Therefore, a reduction in the level of RyR 2 protein does not account for the smaller $\mathrm{Ca}^{2+}$ transient amplitudes in cardiomyocytes from females. Alternatively, sex differences in $\mathrm{Ca}^{2+}$ transients could be explained by alterations in the magnitude and/or duration of individual $\mathrm{SR} \mathrm{Ca}^{2+}$ release units $\left(\mathrm{Ca}^{2+}\right.$ sparks) from RyR2 channels. To investigate this possibility, Farrell et al. [40] compared spontaneous $\mathrm{Ca}^{2+}$ sparks in quiescent myocytes from male and female rats. Figure 1e shows that mean $\mathrm{Ca}^{2+}$ spark amplitudes were significantly smaller in cells from females when compared to males [40]. However, this study also found that there were no differences between the sexes when spark frequency (Fig. 1f) or spark width (not shown) was examined. Females also exhibited lower SR $\mathrm{Ca}^{2+}$ spark durations (time-to-peak and decay time) when compared to males [40]. By contrast, the only other study to examine $\mathrm{Ca}^{2+}$ sparks in males and females contradicted these results, and reported an increase in both $\mathrm{Ca}^{2+}$ spark amplitude and duration in myocytes from female rats [124]. However, this latter study was performed at room temperature, while Farrell et al. [40] examined $\mathrm{Ca}^{2+}$ sparks at physiological temperature. Previous work has shown that $\mathrm{Ca}^{2+}$ sparks recorded at room temperature are larger, have longer durations and occur more frequently when compared to sparks recorded at physiological temperature [41]. It is possible that, in the study by Yaras et al. [124], cooling may have masked sex differences that would be present at physiological temperature in vivo. This is important to consider because many contemporary studies of EC coupling are still conducted at room temperature, which represents a condition of profound hypothermia that influences many aspects of cardiac EC coupling [100].

If $\mathrm{Ca}^{2+}$ sparks are indeed smaller and shorter in myocytes from females, this offers valuable insight into the subcellular basis for sex differences in $\mathrm{SR} \mathrm{Ca}^{2+}$ release and contraction. Smaller $\mathrm{Ca}^{2+}$ sparks would be expected to summate and give rise to smaller $\mathrm{Ca}^{2+}$ transients in cardiomyocytes from females. As the amount of $\mathrm{Ca}^{2+}$ released during a spark is regulated by the intrinsic gating of the RyR2 [16], sex differences in the opening of individual RyR2 channels could be responsible for smaller $\mathrm{Ca}^{2+}$ transients in males. Thus, an important area for future research is determining whether there are sex differences in the gating of RyR2 channels in the SR. Alternatively, as RyR2 levels are actually higher in females $[23,124]$, it is possible that there are post-translational modifications in males that could contribute to increased $\mathrm{SR} \mathrm{Ca}^{2+}$ release by increasing channel opening. Phosphorylation by PKA or CaMKII has been shown to increase the $\mathrm{Ca}^{2+}$-dependent activation and opening of RyRs [5, 126]. As such, reduced SR $\mathrm{Ca}^{2+}$ release in myocytes from female hearts could be a result of a lower level of basal PKA or CaMKII activation. Even in the absence of $\beta$-adrenergic receptor stimulation, lower basal PKA or CaMKII activity could cause less RyR2 phosphorylation and suppress $\mathrm{SR} \mathrm{Ca}^{2+}$ release. Future research into the cAMP/PKA and CaMKII pathways in male and female hearts could be helpful in understanding the cellular basis for sex differences in EC coupling.

Myocytes from male animals respond to isoproterenol, a non-selective $\beta$-adrenergic receptor agonist, with a larger increase in contractions, $\mathrm{Ca}^{2+}$ transient amplitudes and $\mathrm{Ca}^{2+}$ current in comparison to females [29, 113]. Isoproterenol also causes a larger increase in diastolic $\mathrm{Ca}^{2+}$ and SR $\mathrm{Ca}^{2+}$ content in cardiomyocytes from males [19, 29]. These 
effects may be explained by the observation that isoproterenol increases cAMP levels substantially more in cardiomyocytes from males than females [113]. This would cause a greater activation of PKA in male hearts than in females, and thus higher levels of phosphorylation of relevant targets such as L-type $\mathrm{Ca}^{2+}$ channels, RyR2 and PLB. Further studies are required to fully understand the mechanisms that underlie sex differences in responses to $\beta$-adrenergic receptor activation and to determine whether these mechanisms contribute to sex differences in EC coupling even in the absence of $\beta$-adrenergic stimulation.

Electrophysiological studies of EC coupling in ventricular myocytes from males and females

It has been well documented that the size of the $\mathrm{Ca}^{2+}$ transients in ventricular myocytes is directly proportional to the magnitude of the L-type $\mathrm{Ca}^{2+}$ current [6]. To determine whether smaller $\mathrm{Ca}^{2+}$ transients in females could be explained by a decrease in $\mathrm{Ca}^{2+}$ current density, $\mathrm{Ca}^{2+}$ currents have been compared in myocytes from males and females. Representative $\mathrm{Ca}^{2+}$ current recordings from voltage clamp experiments in ventricular myocytes from male and female rats are shown in the lower panel of Fig. 1a [40]. Mean data clearly show that there is no sex difference in $\mathrm{Ca}^{2+}$ current density (Fig. 1g). Indeed, most investigations utilizing ventricular myocytes from rats, mice or guinea pigs have reported no sex difference in $\mathrm{Ca}^{2+}$ current density [9, $40,46,55,65,124]$. In addition, a few studies in various animal models have reported that $\mathrm{Ca}^{2+}$ current density is actually higher in myocytes from females in comparison to males [73, 113, 123]. Taken together, there is considerable evidence that a reduction in $\mathrm{Ca}^{2+}$ current density does not explain the smaller $\mathrm{Ca}^{2+}$ transients and contractions observed in cardiomyocytes from female animals.

Only one study has reported that $\mathrm{Ca}^{2+}$ current density is lower in myocytes from female guinea pigs [56]. However, this study was designed to determine whether $\mathrm{Ca}^{2+}$ current density fluctuated with the oestrous cycle and therefore utilized female guinea pigs that were cycling regularly. Interestingly, they found that $\mathrm{Ca}^{2+}$ current differed between the sexes only on day 4 of the oestrous cycle, which corresponds to the peak in plasma progesterone-to-estradiol levels [56]. However, the influence of the oestrous cycle may not be a factor in most experimental studies, as female rodents housed in groups typically do not cycle regularly $[1,74,119]$ unless they are induced to cycle by exposure to the pheromones present in male urine [118]. Still, the oestrous stage may be an important variable to consider in studies of female animals if they are exhibiting regular oestrous cycles.

A number of investigations have used molecular approaches to determine whether L-type $\mathrm{Ca}^{2+}$ channel expression differs in male and female myocardium. The levels of mRNA for $\mathrm{Ca}_{\mathrm{V}} 1.2$, a subunit of the L-type $\mathrm{Ca}^{2+}$ channel, have been evaluated in hearts from males and females. There is little agreement on whether $\mathrm{Ca}_{V} 1.2$ mRNA levels differ between the sexes, as levels have been shown to increase, decrease or not change at all in ventricles from females when compared to males [23, 102, 106], reflecting inherent limitations in such an approach. A more direct approach is to evaluate the levels of $\mathrm{Ca}_{\mathrm{V}} 1.2$ protein expression in hearts from males and females. These studies showed that female animals have significantly higher levels of $\mathrm{Ca}_{\mathrm{V}} 1.2$ protein in comparison to males [23, 102]. Similarly, Vizgirda et al. [113] used a radioligand binding approach and reported an increase in the density of dihydropyridine receptors (L-type $\mathrm{Ca}^{2+}$ channels) in the ventricles of female rats. If females do have higher levels of $\mathrm{Ca}_{\mathrm{V}} 1.2$, it is interesting that most studies have found that $\mathrm{Ca}^{2+}$ current density does not differ between the sexes. It is possible that there are sex differences in the activity of individual L-type $\mathrm{Ca}^{2+}$ channels. For example, if myocytes from male animals had a higher basal level of PKA activation, then this would result in more $\mathrm{Ca}^{2+}$ channel phosphorylation that could compensate for the decrease in $\mathrm{Ca}^{2+}$ channel expression. Future research should focus on this possibility, as well as other post-translational modifications that may give rise to sex differences in EC coupling.

When cardiomyocytes are regularly paced to reach steady state, $\mathrm{Ca}^{2+}$ efflux from the cytosol must match the $\mathrm{Ca}^{2+}$ entering the cytosol upon depolarization [7]. The primary mechanism responsible for $\mathrm{Ca}^{2+}$ efflux is the $\mathrm{NCX}$, so studies have compared the abundance and activity of the NCX in hearts from males and females. One study found no difference in the NCX current in ventricular myocytes isolated from male and female pig hearts [117]. Conversely, studies in the rabbit model have found an increase in NCX current in myocytes from the base of female ventricles when compared to males [18]. In addition, the expression of NCX1 protein, the major cardiac NCX isoform, is increased in female rabbit hearts [18]. These results are supported by two other studies that showed an increase in NCX protein and mRNA levels in myocytes from female rats in comparison to males [23, 106]. Taken together, these results suggest that both the level of NCX expression and its activity are higher in females than in males, at least in the rat model. Higher NCX activity could contribute to the lower diastolic $\mathrm{Ca}^{2+}$ concentrations and smaller $\mathrm{Ca}^{2+}$ transients observed in myocytes from female rats.

Most of the evidence available to date indicates that $\mathrm{Ca}^{2+}$ current density is similar in cardiomyocytes from males and females, but contractions and $\mathrm{Ca}^{2+}$ transients are smaller in females. This suggests that the "gain" of EC coupling, which is the amount of SR $\mathrm{Ca}^{2+}$ released per unit $\mathrm{Ca}^{2+}$ current, may be lower in cardiomyocytes from females. To 
directly explore this idea, Farrell et al. [40] measured the gain of EC coupling in voltage clamp experiments where $\mathrm{Ca}^{2+}$ current density and $\mathrm{Ca}^{2+}$ transients were measured simultaneously. They found that gain was substantially lower in female rat ventricular myocytes when compared to agematched males. Mean data from this study are shown in Fig. 1h. These data show that less $\mathrm{SR} \mathrm{Ca}^{2+}$ is released in response to a given trigger $\mathrm{Ca}^{2+}$ stimulus in myocytes from females than in males. As previously suggested, future research should examine the possibility that males possess increased phosphorylation levels as a result of higher PKA or CaMKII activity. This could potentially explain the larger $\mathrm{SR} \mathrm{Ca}^{2+}$ release in response to the same amount of trigger $\mathrm{Ca}^{2+}$. Alternatively, it has been suggested that sex steroid hormones are responsible for the decrease in EC coupling gain in female myocytes in comparison to males [71]. Further understanding of the cardiomyocyte pathways activated by the major sex steroid hormones is required.

The data reviewed above indicate that sex differences in EC coupling are likely due to alterations in the regulation of $\mathrm{SR} \mathrm{Ca}^{2+}$ release, rather than differences in $\mathrm{Ca}^{2+}$ influx, at least when cells are activated by identical square pulses in voltage clamp experiments. However, $\mathrm{SR} \mathrm{Ca}^{2+}$ release and cardiac contraction in vivo are triggered by an action potential, not a square voltage clamp waveform. Investigations in various animal models have compared action potential characteristics between the sexes. Studies in cardiomyocytes from C57BL/6 mice, rats and guinea pigs have found that action potential durations at $50 \%$ and $90 \%$ repolarization $\left(\mathrm{APD}_{50}\right.$ and $\left.\mathrm{APD}_{90}\right)$ are similar in males and females [9, 10, $40,65]$. However, this finding has not been observed in all studies. APDs are prolonged in CD-1 female mice when compared to males [109]. APD is also prolonged in ventricular myocytes from the midmyocardium of female dogs [123]. There is evidence that ventricular myocytes from female guinea pigs have longer APDs than males [73], although another study found longer APDs in females only when the animals were in the "oestrus" stage, where estradiol levels had peaked [56]. Interestingly, prolongation of the APD in female mice is also most readily apparent when mice are in the "oestrus" stage [93]. Differences in the species used, source of the ventricular myocytes used and/or the oestrous stage may account for these divergent results. Nonetheless, these studies show that APD is either similar in cardiomyocytes from males and females or that it is prolonged in females. As prolongation of the action potential increases $\mathrm{Ca}^{2+}$ influx [25], this may help compensate for the reduction in $\mathrm{SR} \mathrm{Ca}^{2+}$ release in female myocytes in vivo. Additional experiments to explore the relationship between APD and myocardial $\mathrm{Ca}^{2+}$ handling in myocytes from males and females are needed. Important functional differences in cardiac EC coupling mechanisms in myocytes from female rodents in comparison to males are summarized in Fig. 2.

\section{The impact of sex steroid hormones on cardiac EC coupling mechanisms}

The risk of cardiovascular disease is lower in pre-menopausal women in comparison to age-matched men; this difference disappears as early as 5 years post-menopause $[8,53,54]$. As menopause is marked by a decrease in the production of ovarian hormones, it is thought that female sex hormones are cardioprotective, and their decline contributes to the increased risk of cardiovascular disease during the aging process [69]. Indeed, there is some evidence that hormone replacement therapy reduces the risk of cardiovascular disease in post-menopausal women, although this is controversial [78]. It is less often appreciated that men also experience an agedependent decline in the levels of sex hormones during andropause, at the same time as their risk of cardiovascular disease rises [30, 61]. Testosterone supplementation, which is currently used to treat various conditions linked to low androgen states, is being explored for the treatment of cardiovascular diseases [61]. These observations have led to considerable interest in the mechanisms by which sex steroid hormones may modify cardiovascular function.

The knowledge that individual cardiomyocytes possess receptors for all three major sex steroid hormones (oestrogen, progesterone and testosterone) has led to the idea that effects of sex hormones on the myocytes themselves may be important in understanding their role in cardiovascular disease $[30,79]$. Sex hormones are thought to act via specific receptors to elicit both non-genomic (acute) and genomic (chronic) effects on cardiac contractile function $[30,79]$. As such, it is possible that sex hormones play an important role in mediating the sex differences in EC coupling observed in cardiomyocytes from male and female animals. The following discussion will first consider acute and chronic effects of female sex hormones on cardiac function. This will be followed by consideration of the impact of male sex hormones on the heart.

\section{Acute effects of female sex hormones on EC coupling}

As neonatal and adult cardiomyocytes possess oestrogen receptors [47, 91], there has been considerable interest in the acute (non-genomic) effects of oestrogen on cardiomyocyte function. Therefore, a number of studies have explored the effects of acute administration of oestrogen on components of the EC coupling pathway. It is well established that acute application of supra-physiological concentrations (e.g. 0.1 to $100 \mu \mathrm{M}$ ) of the major female sex steroid hormone, $17 \beta$-estradiol, to ventricular myocytes causes a marked reduction in the magnitude of the $\mathrm{Ca}^{2+}$ current in myocytes from mice, rats, guinea pigs, rabbits and even humans $[3,57$, 77, 105, 110]. Meyer et al. [77] showed that $10 \mu \mathrm{M} 17 \beta$ estradiol elicited a similar inhibitory action on the $\mathrm{Ca}^{2+}$ current 
Fig. 2 Differences in the major components of cardiac excitationcontraction (EC) coupling in ventricular myocytes from female animals in comparison to males. L-type $\mathrm{Ca}^{2+}$ current density does not differ between males and females, although NCX activity is higher in myocytes from females. However, $\mathrm{Ca}^{2+}$ transient amplitudes and $\mathrm{SR} \mathrm{Ca}^{2+}$ spark amplitudes are decreased in females in comparison to males. Therefore, females have lower EC coupling gain $\left(\mathrm{Ca}^{2+}\right.$ transient per unit $\mathrm{Ca}^{2+}$ current). Female myocytes have smaller contractions in comparison to males. Contractions are also slower to relax in female myocytes, which is likely a result of reduced $\mathrm{SR} \mathrm{Ca}^{2+}$ uptake via SERCA. Additionally, APD is either unchanged or prolonged in myocytes from females in comparison to cells from males. These sex differences in EC coupling are thought to contribute to reduced contractile function in myocytes from females in comparison to males. APD action potential duration, $N C X \mathrm{Na}^{+}-\mathrm{Ca}^{2+}$ exchanger, $P L B$ phospholamban, $R y R$ ryanodine receptor, $S E R C A$ sarcoplasmic/endoplasmic reticulum $\mathrm{Ca}^{2+}$ ATPase, $S R$ sarcoplasmic reticulum

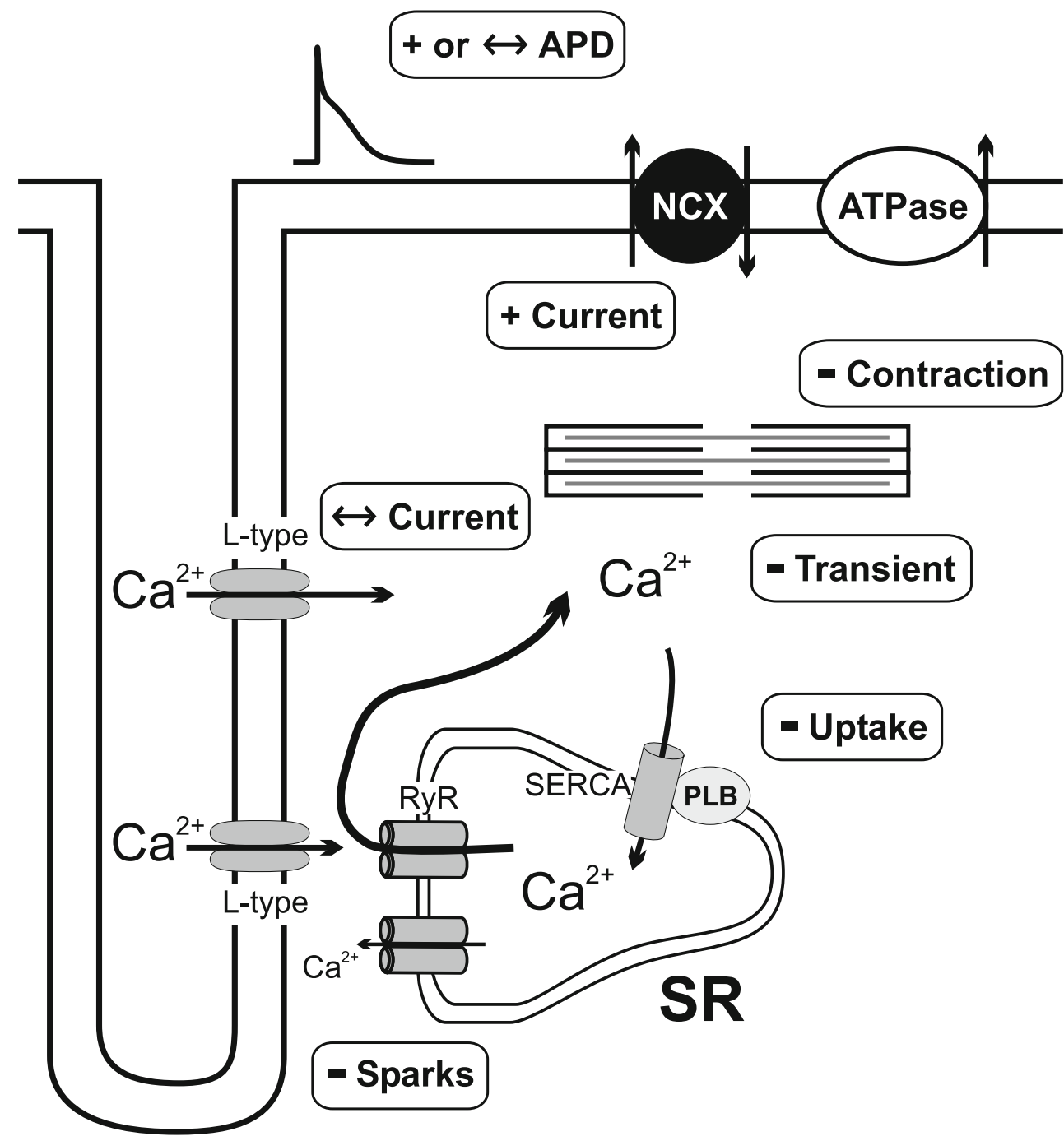

in cells from humans, guinea pigs and rats, regardless of whether the cells were from males or females. Acute application of high concentrations (10 to $30 \mu \mathrm{M})$ of $17 \beta$-estradiol also reduces the amplitudes of $\mathrm{Ca}^{2+}$ transients and contractions in isolated ventricular myocytes [57, 110]. Interestingly, stimulation of oestrogen receptor $\alpha$ with PPT $(4,49,499$-(4-propyl-[1H]-pyrazole-1,3,5triyl) trisphenol; $100 \mathrm{nM}$ ) has been shown to decrease myofilament $\mathrm{Ca}^{2+}$ sensitivity [64]. There is also evidence that oestrogen can acutely modify electrophysiological properties of the heart. Langendorff-perfused female rabbit hearts [21] showed that $17 \beta$-estradiol (1 to $30 \mu \mathrm{M}$ ) prolonged APD and increased the incidence of arrhythmias induced by the Class III antiarrhythmic drug, sotalol. These studies provide evidence that acute application of supra-physiological concentrations of $17 \beta$-estradiol can affect components of the EC coupling pathway. However, serum concentrations of $17 \beta$-estradiol range from 70 to $1,300 \mathrm{pM}$ depending upon the menstrual cycle in premenopausal women [30].
Serum estradiol levels are reported to be even lower in rodent models and are very difficult to accurately and consistently measure [51, 75, 93, 121]. Even so, all studies of the acute effects of oestrogen on cardiomyocytes to date have utilized very high concentrations of $17 \beta$-estradiol. It would be interesting to investigate acute effects of picomolar concentrations of $17 \beta$-estradiol in vitro.

The other major female sex hormone is progesterone, and previous studies have shown that progesterone receptors are also present on cardiomyocytes [45]. There is some evidence that the acute application of progesterone can affect various components of the EC coupling pathway. One study found that acute treatment with very high concentrations of progesterone ( 1 to $3 \mu \mathrm{M})$ increased APD in Langendorffperfused female rabbit hearts [21]. By contrast, lower concentrations of progesterone (e.g. $100 \mathrm{nM}$ ) have been shown to reduce APD in cardiomyocytes isolated from female guinea pigs [80]. This effect was found to be due mainly to a progesterone-mediated increase in the magnitude of the 
slow delayed rectifier $\mathrm{K}^{+}$current $\left(I_{\mathrm{Ks}}\right)$, which is an important contributor to cellular repolarization [80]. Progesterone $(100 \mathrm{nM})$ also attenuates the increase in Ltype $\mathrm{Ca}^{2+}$ current that occurs in response to $\beta$ adrenergic stimulation with isoproterenol [80]. Together, these studies suggest that relatively high concentrations of progesterone $(0.1$ to $3 \mu \mathrm{M})$ can affect myocardial function at the cellular level. However, these studies have all utilized relatively high concentrations of the hormone; circulating levels of progesterone range from 1 to $64 \mathrm{nM}$ in premenopausal women [30] and between 3 and $55 \mathrm{nM}$ in rodents [60, 121]. Whether lower concentrations of progesterone affect the contractile function of cardiomyocytes in vitro should be further examined.

The impact of ovariectomy on EC coupling

Inferences about the effects of chronic exposure to gonadally derived oestrogen on cardiac function have been drawn from investigations where animals have been subjected to bilateral ovariectomy (OVX), in the absence and/or presence of oestrogen replacement. Bilateral OVX causes a dramatic reduction in circulating levels of the primary female sex hormone, $17 \beta$ estradiol [22, 34, 58, 88, 122]. Several studies have compared contractile function in ventricular myocytes isolated from sham-operated and OVX rodents, with conflicting results. Two studies found an increase in contraction size in cells from OVX rats in comparison to sham controls after 3-6 weeks of steroid withdrawal $[28,122]$. By contrast, contractions were reported to be smaller in myocytes isolated from rats following 9-10 weeks of steroid withdrawal [14, 88]. Results from these studies are summarized in Table 2. Interestingly, in all cases, these effects of OVX on cardiac contractile function were reversed when $17 \beta$-estradiol was replaced [14, 28, 88, 122]. It is not clear why differing results were obtained in these studies, but it is possible that the time frame of steroid withdrawal is important in the observed effects on cardiac contraction at the cellular level. Additional investigation of the impact of varying time periods of OVX may be revealing.

A number of studies also have investigated whether OVX affects SR $\mathrm{Ca}^{2+}$ release at the level of the cardiomyocyte. Figure 3a shows mean results obtained by Fares et al. [39] from voltage clamp experiments performed on isolated cardiomyocytes from sham-operated and OVX mice. These data show that OVX causes a marked increase in mean peak $\mathrm{Ca}^{2+}$ transients in myocytes from OVX animals when compared to sham controls. Most other investigations in the rat model have also shown that peak $\mathrm{Ca}^{2+}$ transient amplitudes are increased by OVX when compared to sham-operated controls, and this effect is reversed by $17 \beta$-estradiol replacement $[28,39,63,70]$. Together, these studies have investigated periods of hormone withdrawal as short as 3 weeks and as long as 26 weeks (Table 2), suggesting that the period of hormone restriction may not affect the observed results $[28,39,63,70]$. In contrast to these findings, two studies have reported that peak $\mathrm{Ca}^{2+}$ transients are either unchanged or reduced following OVX in the rat model [14, 88]. However, these latter studies used slow pacing rates (e.g. $0.5 \mathrm{~Hz}$ ) and buffers that contained only 0.5 to $1 \mathrm{mM} \mathrm{Ca}^{2+}$, factors that have been shown to reduce SR $\mathrm{Ca}^{2+}$ loading and eliminate sex differences in cardiac EC coupling [83]. These factors may have reduced the amount of SR $\mathrm{Ca}^{2+}$ available for release in OVX myocytes.

Insights into the effects of chronic oestrogen exposure on cardiac contractile function have also been drawn from comparisons of myofilament $\mathrm{Ca}^{2+}$ sensitivity in cardiac tissues from sham-operated and OVX rats. There is good agreement that myofilament $\mathrm{Ca}^{2+}$ sensitivity is increased in OVX hearts after 10 weeks of steroid withdrawal when

Table 2 Components of cardiac EC coupling in ventricular myocytes from OVX animals in relation to responses in sham-operated controls

\begin{tabular}{|c|c|c|c|c|}
\hline Parameter & Change & Model & $\begin{array}{l}\text { Steroid } \\
\text { withdrawal } \\
\text { (weeks) }\end{array}$ & References \\
\hline \multirow[t]{4}{*}{ Contraction } & \multirow[t]{2}{*}{$\uparrow$ Shortening } & \multirow[t]{2}{*}{ Rats } & 3 & {$[28]$} \\
\hline & & & 6 & [122] \\
\hline & \multirow[t]{2}{*}{$\downarrow$ Shortening } & \multirow[t]{2}{*}{ Rats } & 9 & [88] \\
\hline & & & 10 & [14] \\
\hline \multirow[t]{6}{*}{$\mathrm{Ca}^{2+}$ transient } & \multirow[t]{4}{*}{$\uparrow$ Amplitude } & \multirow[t]{3}{*}{ Rats } & 3 & {$[28]$} \\
\hline & & & 6 & {$[63]$} \\
\hline & & & 9 & {$[70]$} \\
\hline & & Mice & 26 & [39] \\
\hline & $\leftrightarrow$ Amplitude & Rats & 9 & {$[88]$} \\
\hline & $\downarrow$ Amplitude & Rats & 10 & [14] \\
\hline \multirow[t]{2}{*}{ Myofilaments } & \multirow{2}{*}{$\begin{array}{l}\uparrow \mathrm{Ca}^{2+} \\
\text { sensitivity }\end{array}$} & Rats & 10 & [14] \\
\hline & & Rats & 10,14 & [115] \\
\hline $\begin{array}{l}\mathrm{SR} \mathrm{Ca}^{2+} \\
\text { sparks }\end{array}$ & $\begin{array}{c}\uparrow \text { Frequency, } \\
\text { amplitude }\end{array}$ & Mice & 26 & [39] \\
\hline \multirow{2}{*}{$\begin{array}{l}\mathrm{SR} \mathrm{Ca}^{2+} \\
\text { content }\end{array}$} & \multirow[t]{2}{*}{$\uparrow$ Stores } & Rats & 6 & {$[63]$} \\
\hline & & Mice & 26 & [39] \\
\hline $\mathrm{Ca}^{2+}$ current & $\leftrightarrow$ Density & Mice & 26 & {$[39]$} \\
\hline \multirow{6}{*}{$\begin{array}{l}\text { Diastolic } \\
\mathrm{Ca}^{2+}\end{array}$} & \multirow[t]{3}{*}{$\leftrightarrow$ Levels } & \multirow[t]{3}{*}{ Rats } & 3 & {$[28]$} \\
\hline & & & 6 & {$[63]$} \\
\hline & & & 10 & {$[14]$} \\
\hline & \multirow[t]{3}{*}{$\uparrow$ Levels } & \multirow[t]{2}{*}{ Rats } & 9 & {$[70]$} \\
\hline & & & 9 & [88] \\
\hline & & Mice & 26 & [39] \\
\hline NCX current & $\uparrow$ Density & Rats & 6 & {$[63]$} \\
\hline
\end{tabular}

$O V X$ ovariectomy, $N C X \mathrm{Na}^{+}-\mathrm{Ca}^{2+}$ exchanger, $S R$ sarcoplasmic reticulum 
A
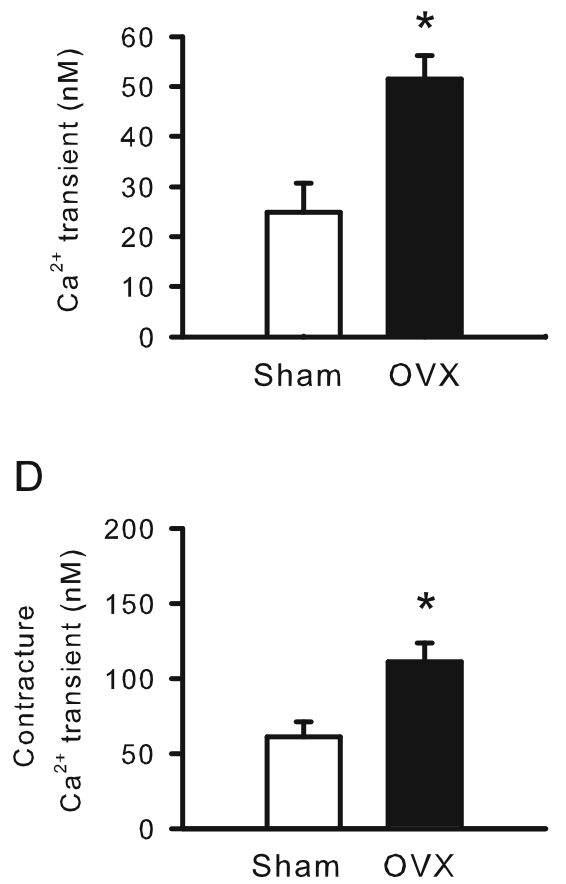

Fig. 3 Ovariectomy modifies components of EC coupling to enhance $\mathrm{SR} \mathrm{Ca}^{2+}$ release in isolated ventricular myocytes. EC coupling mechanisms were compared in ventricular myocytes isolated from 8-monthold female mice that had either a bilateral OVX or sham operation at 1 month of age. $\mathrm{Ca}^{2+}$ transients and $\mathrm{Ca}^{2+}$ currents were activated by a voltage clamp step from -40 to $0 \mathrm{mV}$. a Ca ${ }^{2+}$ transient amplitudes were significantly larger in myocytes from OVX mice when compared to

compared to sham-operated controls $[14,115,116]$. Furthermore, treatment with oestrogen replacement reversed these changes in myofilament $\mathrm{Ca}^{2+}$ sensitivity [116]. Together with the majority of studies that show that OVX increases $\mathrm{SR} \mathrm{Ca}^{2+}$ release, this sensitization of the myofilaments to $\mathrm{Ca}^{2+}$ would be expected to augment cardiac contractile function. However, whether OVX increases contraction at the level of the cardiomyocyte remains controversial and is an interesting area for additional exploration.

The finding that OVX causes an increase in $\mathrm{Ca}^{2+}$ transient amplitudes suggests that oestrogen may suppress SR $\mathrm{Ca}^{2+}$ release. To further examine this possibility, Fares et al. [39] compared the occurrence and properties of individual $\mathrm{Ca}^{2+}$ units (spontaneous $\mathrm{Ca}^{2+}$ sparks) in ventricular myocytes from sham-operated and OVX mice. Although spark duration was unaffected by OVX, they found that spontaneous $\mathrm{Ca}^{2+}$ sparks were more frequent and larger in amplitude in myocytes from OVX mice in comparison to cells from sham controls (Fig. 3b, c and Table 2). This finding demonstrates that unitary $\mathrm{SR} \mathrm{Ca}^{2+}$ release is enhanced by chronic oestrogen withdrawal and suggests that oestrogen may reduce $\mathrm{Ca}^{2+}$ transient amplitudes by suppressing $\mathrm{Ca}^{2+}$ release at the level of the individual SR $\mathrm{Ca}^{2+}$ release unit. Additional experiments to determine whether oestrogen
C

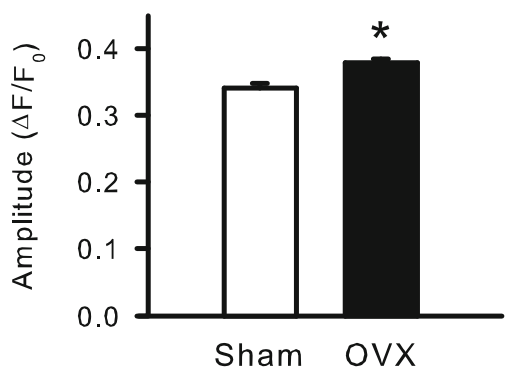

$\mathrm{F}$

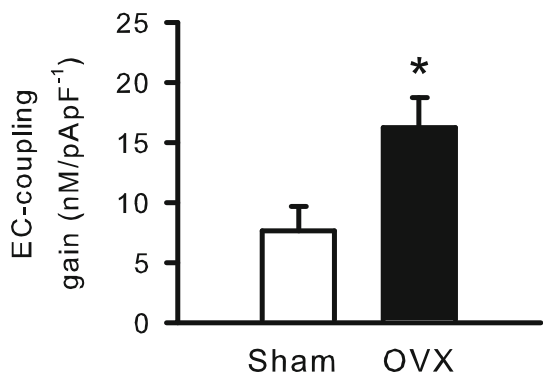

sham-operated controls. b, c Spontaneous $\mathrm{Ca}^{2+}$ sparks were larger and occurred more frequently in OVX myocytes when compared to sham controls. d OVX increased SR $\mathrm{Ca}^{2+}$ content, as measured via rapid application of $10 \mathrm{mM}$ caffeine. $\mathrm{e} \mathrm{Ca}^{2+}$ current densities were similar in myocytes from OVX and sham-operated animals. f OVX increased the gain of EC coupling. Reprinted from Fares et al. [39] with permission

replacement could reverse these changes would provide further support for this idea.

One factor that may modify $\mathrm{Ca}^{2+}$ release in OVX myocytes is $\mathrm{SR} \mathrm{Ca}^{2+}$ content. Thus, $\mathrm{SR} \mathrm{Ca}{ }^{2+}$ content has been compared in cardiomyocytes isolated from sham-operated and OVX rodents. Fares et al. [39] used the rapid application of $10 \mathrm{mM}$ caffeine to measure SR $\mathrm{Ca}^{2+}$ load. They showed that OVX increased SR $\mathrm{Ca}^{2+}$ content in murine cardiomyocytes, as shown in the mean data illustrated in Fig. 3d. Indeed, there is good agreement that cardiomyocytes from OVX mice and rats have increased $\mathrm{SR} \mathrm{Ca}^{2+}$ stores in comparison to shamoperated controls $[39,63]$. These data indicate that OVX increases the amount of $\mathrm{Ca}^{2+}$ available in the SR, which would be expected to contribute to the larger $\mathrm{Ca}^{2+}$ transients characteristic of OVX myocytes. This increase in $\mathrm{SR} \mathrm{Ca}^{2+}$ content may explain the increased frequency of $\mathrm{Ca}^{2+}$ sparks in OVX cells. Spontaneous $\mathrm{Ca}^{2+}$ sparks are thought to be a pathway to limit SR $\mathrm{Ca}^{2+}$ overload [94], so the increased spark frequency in OVX cells likely occurs in response to the increase in SR $\mathrm{Ca}^{2+}$ content.

Elevated $\mathrm{SR} \mathrm{Ca}^{2+}$ content can also lead to spontaneous release of a larger amount of SR $\mathrm{Ca}^{2+}$ and trigger delayed afterdepolarizations, leading to cardiac arrhythmias [103]. Interestingly, OVX has been shown to promote the 
spontaneous release of $\mathrm{SR} \mathrm{Ca}^{2+}$ [39]. This may explain previous observations that OVX increases arrhythmias in myocardial ischemia and during adrenergic stimulation [24, 107] and could, in part, explain the increase in risk for arrhythmias in post-menopausal women [82]. Taken together, these results suggest that oestrogen suppresses SR $\mathrm{Ca}^{2+}$ release, limits $\mathrm{SR} \mathrm{Ca}^{2+}$ content and inhibits the spontaneous release of $\mathrm{SR} \mathrm{Ca}^{2+}$. This may contribute to the cardioprotective effects of oestrogen observed in both clinical and laboratory studies.

Since the magnitude of $\mathrm{SR} \mathrm{Ca}^{2+}$ release is directly proportional to the amount of $\mathrm{Ca}^{2+}$ entering the cell upon depolarization [6], differences in $\mathrm{Ca}^{2+}$ current between OVX and sham controls could account for the variability in $\mathrm{Ca}^{2+}$ transient amplitudes. Previous studies have shown that $\mathrm{Ca}_{\mathrm{V}} 1.2$ protein expression is higher in hearts from OVX rats in comparison to sham controls [22]. However, Fares et al. [39] directly measured L-type $\mathrm{Ca}^{2+}$ current in ventricular myocytes from sham-operated and OVX mice and found that peak $\mathrm{Ca}^{2+}$ currents were similar in the two groups, as shown in Fig. 3e. Mean data from this study also showed that $\mathrm{Ca}^{2+}$ current amplitudes were similar in sham and OVX cells across a range of voltages [39]. This indicates that the increased $\mathrm{Ca}^{2+}$ transients observed in OVX cardiomyocytes are not a result of increased $\mathrm{Ca}^{2+}$ influx. In fact, the same study reported that OVX increased the gain of EC coupling in comparison to sham controls, as shown in Fig. 3f [39]. Overall, these studies suggest that female sex steroid hormones, such as oestrogen, reduce $\mathrm{SR} \mathrm{Ca}^{2+}$ release by modifying the gain of EC coupling, not by suppressing $\mathrm{Ca}^{2+}$ influx.

Whether OVX affects resting $\mathrm{Ca}^{2+}$ levels in isolated cardiomyocytes has been investigated in a number of studies, as summarized in Table 2. When diastolic $\mathrm{Ca}^{2+}$ levels were quantified 3 to 6 weeks after OVX, diastolic $\mathrm{Ca}^{2+}$ levels were similar in sham and OVX myocytes [28, 63]. One study has reported that diastolic $\mathrm{Ca}^{2+}$ levels were unchanged even 10 weeks after OVX [14], although most studies that looked at longer times after OVX (e.g. 9 to 26 weeks) found that diastolic $\mathrm{Ca}^{2+}$ levels were higher in cardiomyocytes from OVX animals in comparison to sham controls $[39,70,88]$. These findings suggest that prolonged periods of oestrogen withdrawal may increase resting $\mathrm{Ca}^{2+}$ levels in ventricular myocytes. This could promote impaired relaxation and diastolic dysfunction in older female hearts that are chronically exposed to lower ovarian hormone levels, and further studies of this are warranted.

Elevated diastolic $\mathrm{Ca}^{2+}$ suggests that $\mathrm{Ca}^{2+}$ extrusion mechanisms may be compromised by OVX. Thus, several studies have evaluated whether OVX modifies $\mathrm{Ca}^{2+}$ handling by affecting $\mathrm{Ca}^{2+}$ sequestration and/or removal mechanisms. There is evidence that the levels of SERCA2a protein are unchanged after OVX [22, 63, 88], although two studies have found that SERCA2a levels decline following longer periods of hormone withdrawal (e.g. 10 weeks $[12,13])$. However, whether this impairs $\mathrm{SR} \mathrm{Ca}^{2+}$ sequestration has not been established. While total PLB and phospho-Ser ${ }^{16}$ PLB are not affected by OVX, phospho-Thr ${ }^{17}$ PLB has been shown to decrease with OVX [12, 13], which could actually enhance $\mathrm{SR} \mathrm{Ca}^{2+}$ uptake. Additional studies to clarify this issue would be of interest. There is no evidence that NCX protein levels are increased by OVX [22, 63], although functional studies have reported an increase in NCX activity in cardiomyocytes isolated from rats 6 weeks after OVX [63]. This would be expected to promote $\mathrm{Ca}^{2+}$ extrusion and reduce resting $\mathrm{Ca}^{2+}$ levels, at least in the short term. Whether this persists with longer periods of ovarian hormone withdrawal has not yet been determined.

To elucidate the molecular mechanisms responsible for enhanced SR $\mathrm{Ca}^{2+}$ release following OVX, several studies have examined the contribution of phosphorylation of EC coupling components. Application of isoproterenol causes a greater increase in $\mathrm{Ca}^{2+}$ current, $\mathrm{Ca}^{2+}$ transients and PKA activity in myocytes from OVX rats compared to sham controls [58]. This may be due, at least in part, to the higher levels of $\beta_{1}$-adrenergic receptors observed in OVX cardiomyocytes $[108,122]$. Even acute application of physiological concentrations of $17 \beta$-estradiol $(0.1$ to $1 \mathrm{nM})$ attenuates the increase in cAMP levels caused by isoproterenol application [66]. Although no basal differences in cAMP levels are observed, myocytes from OVX rats have increased basal PKA expression and activity [58, 63]. Interestingly, Kravtsov et al. [63] showed that pharmacological inhibition of basal PKA abolished the increase in SR $\mathrm{Ca}^{2+}$ release in myocytes from OVX rats. Furthermore, the basal increase in PKA activity was abolished when OVX rats were chronically treated with oestrogen replacement [58]. This suggests that oestrogen may attenuate PKA expression and/or activity in cardiomyocytes. There is also some evidence that implicates the CaMKII pathway in $\mathrm{Ca}^{2+}$ dysregulation in OVX hearts. Levels of CaMKII $\delta$ and phosphorylated CaMKII protein are higher in ventricular tissue from OVX compared to sham controls [70]. This could augment SR $\mathrm{Ca}^{2+}$ release, as CaMKII-dependent phosphorylation of RyR2 is known to increase the amplitude and duration of $\mathrm{Ca}^{2+}$ sparks [50]. Together, these observations suggest that enhanced phosphorylation of various components of the EC coupling pathway may augment $\mathrm{SR} \mathrm{Ca}^{2+}$ release and ultimately cause intracellular $\mathrm{Ca}^{2+}$ dysregulation following sex hormone withdrawal in females. Further studies that focus on sex hormone modulation of signalling pathways that regulate EC coupling could be highly informative.

Even though the ovaries are the primary source of oestrogens, gonadally derived steroid hormones are not the only source of systemic oestrogens in female animals. Other cell types including bone and adipocytes express the enzyme aromatase, which can convert testosterone to $17 ß$ - 
estradiol [101]. Aromatase is expressed in both neonatal tissues and cardiomyocytes [48, 85], as well as in the adult rodent heart [2]. This raises the interesting possibility that androgens can be locally converted to oestrogens in the myocardium [2]. Whether exposure of cardiomyocytes to sex steroid hormones can be regulated at the local tissue level is an important area for further investigation.

Acute and chronic effects of male sex hormones on EC coupling

Previous studies have shown that functional androgen receptors are present on cardiomyocytes $[47,72]$. Therefore, some studies have investigated the effects of both acute and chronic application of testosterone on cardiomyocyte function. Er et al. [36] found that acute application of supraphysiological concentrations of dihydrotestosterone $(100 \mathrm{nM})$ to ventricular myocytes from female rats caused a marked reduction in the magnitude of the $\mathrm{Ca}^{2+}$ current. Interestingly, these authors also showed that treatment with similar amounts of dihydrotestosterone for $24 \mathrm{~h}$ had the opposite effect and enhanced $\mathrm{Ca}^{2+}$ current [36]. This increase in $\mathrm{Ca}^{2+}$ current density was associated with an increase in expression of the $\alpha 1 \mathrm{C}$ subunit of the $\mathrm{Ca}^{2+}$ channel [36]. Acute treatment with $100 \mathrm{nM}$ dihydrotestosterone had no effect on $\mathrm{Ca}^{2+}$ spark frequency or amplitude, but $24 \mathrm{~h}$ treatment increased the frequency of SR $\mathrm{Ca}^{2+}$ sparks, without affecting their amplitude [36]. Interestingly, $24 \mathrm{~h}$ of exposure to $100 \mathrm{nM}$ dihydrotestosterone had no effect on $\mathrm{SR} \mathrm{Ca}^{2+}$ stores in cardiomyocytes $[36,44]$. By contrast, $24 \mathrm{~h}$ of treatment with dihydrotestosterone caused an increase in both $\mathrm{Ca}^{2+}$ transient amplitudes and fractional shortening $[36,44]$. These results suggest that both acute and chronic exposure to high concentrations of testosterone affect intracellular $\mathrm{Ca}^{2+}$ handling. While acute exposure may limit $\mathrm{Ca}^{2+}$ entry, chronic (up to $24 \mathrm{~h}$ ) exposure increases $\mathrm{Ca}^{2+}$ influx and augments both $\mathrm{SR} \mathrm{Ca}^{2+}$ release and contraction. However, physiological levels of testosterone are in the range of 10 $35 \mathrm{nM}$ in adult men [30] and fluctuate around a similar range in rodent models [75]. Additional studies that use more physiological concentrations of testosterone and longer exposure times could be informative.

Very few studies have evaluated the impact of long-term male gonadal steroid hormone withdrawal on cardiac contractile function. Golden et al. [43] used gonadectomised male rats to examine the effect of testosterone withdrawal on cardiac EC coupling. They showed that, 16 weeks after gonadectomy, isolated cardiomyocytes exhibited a significantly slower rate of shortening and relaxation in comparison to sham controls, although there was no difference in peak contraction [43]. When rats were subjected to sex hormone replacement, these differences between sham and gonadectomised animals were abolished [43]. Other studies have examined cardiac muscle strips and isolated myocytes from rats 2 weeks after gonadectomy and reported a decrease in both peak contraction and peak $\mathrm{Ca}^{2+}$ transient amplitudes, as well as slower decay of both responses when compared to controls [26, 120]. Importantly, these changes were reversed after testosterone replacement [26]. These findings indicate that removal of male gonadal steroid hormones inhibits $\mathrm{SR} \mathrm{Ca}^{2+}$ release and suggest that testosterone may augment $\mathrm{SR} \mathrm{Ca}^{2+}$ release. This agrees with the results of previous studies, described above, where testosterone was acutely applied to cardiomyocytes for 24 h. Future studies should investigate the specific components of EC coupling that are affected by testosterone and identify the intracellular signalling pathways that may be implicated in these effects.

\section{Summary}

The past decade has seen advances in our understanding of the impact of sex on cardiac contractile function, although much remains to be investigated. There is growing evidence that peak contractions are smaller and slower in intact hearts and cardiac muscle preparations from females when compared to males. This is due, in large part, to a decrease in the ability of individual cardiomyocytes to contract. Sex differences at several different locations in the EC coupling pathway have been implicated (Fig. 2). Most notably, new studies have shown that cardiomyocytes from female hearts exhibit a marked decrease in the gain of EC coupling, which translates to a decrease in $\mathrm{SR} \mathrm{Ca}^{2+}$ release. This has been observed as lower peak $\mathrm{Ca}^{2+}$ transients and smaller individual $\mathrm{SR} \mathrm{Ca}^{2+}$ sparks in myocytes from females, in comparison to males. Nonetheless, little is known about the specific signalling pathways implicated in these sex differences, and this limits the ability to translate these findings to new therapeutic strategies.

Although information is limited, sex differences in cardiac contractile function may be linked to effects of the major sex hormones on components of the EC coupling pathway. There is some evidence that acute application of high concentrations of $17 \beta$-estradiol, progesterone or testosterone can modify EC coupling mechanisms. However, whether more physiological concentrations of these hormones have similar effects is not yet clear. There is evidence from studies in ovariectomized rodents that chronic reduction in circulating $17 \beta$-estradiol modifies EC coupling mechanisms. Importantly, OVX causes a marked increase in the gain of EC coupling, resulting in larger peak $\mathrm{Ca}^{2+}$ transients and larger $\mathrm{Ca}^{2+}$ sparks. These results strongly suggest that oestrogen suppresses $\mathrm{SR} \mathrm{Ca}^{2+}$ release and contributes importantly to the reduction in EC coupling gain present in cardiomyocytes from females. OVX also promotes cardiomyocyte $\mathrm{Ca}^{2+}$ dysregulation, including elevated $\mathrm{SR} \mathrm{Ca}^{2+}$ 
content and larger unitary $\mathrm{Ca}^{2+}$ release events. This SR $\mathrm{Ca}^{2+}$ overload promotes the spontaneous release of $\mathrm{Ca}^{2+}$ from the SR. This could increase susceptibility to a range of different cardiovascular diseases in low oestrogen states, such as in older, post-menopausal women. New research that explores the intracellular signalling pathways involved in these effects could lead to the identification of new targets for the treatment of cardiovascular diseases in older women.

There is a growing literature that suggests that oestrogen contributes to sex differences in myocardial contractile function, although this work is far from complete. Even less attention has been paid to the effects of testosterone on cardiac contraction, either at the intact heart level or at the cellular level. Intriguing evidence suggests that chronic reduction in circulating testosterone levels reduces the contractility of individual cardiomyocytes and suppresses $\mathrm{Ca}^{2+}$ transients. This raises the possibility that testosterone may increase intracellular $\mathrm{Ca}^{2+}$ levels through effects on $\mathrm{EC}$ coupling mechanisms, although this has not yet been investigated. If the loss of testosterone reduces intracellular $\mathrm{Ca}^{2+}$ levels in older men, this could suppress contractile function and contribute to systolic dysfunction in this population.

These findings that implicate sex hormone-regulated signalling pathways in the modulation of cardiac contractile function are potentially very important. If sex hormones such as oestrogen and testosterone are primary determinants of EC coupling gain, understanding the signalling pathways that regulate these actions can shed light on unique factors responsible for differences in cardiovascular disease expression in older men and women. This could lead to the identification of potential targets for the development of new agents to treat diseases such as cardiac contractile dysfunction and systolic heart failure in both men and women.

Acknowledgments The authors express their appreciation to Peter Nicholl for assistance with figures. This study was supported by grants from the Canadian Institutes for Health Research and the Heart and Stroke Foundation of New Brunswick. Randi Parks was supported by awards from the Nova Scotia Health Research Foundation and the Dalhousie Medical Research Foundation.

Open Access This article is distributed under the terms of the Creative Commons Attribution License which permits any use, distribution, and reproduction in any medium, provided the original author(s) and the source are credited.

\section{References}

1. Barkley MS, Bradford GE (1981) Estrous cycle dynamics in different strains of mice. Proc Soc Exp Biol Med 167:70-77

2. Bell JR, Mellor KM, Wollermann AC, Ip WT, Reichelt ME, Meachem SJ, Simpson ER, Delbridge LM (2011) Aromatase deficiency confers paradoxical postischemic cardioprotection. Endocrinology 152:4937-4947
3. Berger F, Borchard U, Hafner D, Putz I, Weis TM (1997) Effects of 17beta-estradiol on action potentials and ionic currents in male rat ventricular myocytes. Naunyn Schmiedebergs Arch Pharmacol 356:788-796

4. Bers DM (2001) Excitation-contraction coupling and cardiac contractile force, 2nd edn. Kluwer Academic, Dordrecht

5. Bers DM (2002) Cardiac excitation-contraction coupling. Nature 415:198-205

6. Bers DM (2008) Calcium cycling and signaling in cardiac myocytes. Annu Rev Physiol 70:23-49

7. Bers DM, Bassani JW, Bassani RA (1996) Na-Ca exchange and $\mathrm{Ca}$ fluxes during contraction and relaxation in mammalian ventricular muscle. Ann N Y Acad Sci 779:430-442

8. Bhupathy P, Haines CD, Leinwand LA (2010) Influence of sex hormones and phytoestrogens on heart disease in men and women. Womens Health (Lond Engl) 6:77-95

9. Brouillette J, Lupien MA, St-Michel C, Fiset C (2007) Characterization of ventricular repolarization in male and female guinea pigs. J Mol Cell Cardiol 42:357-366

10. Brouillette J, Rivard K, Lizotte E, Fiset C (2005) Sex and strain differences in adult mouse cardiac repolarization: importance of androgens. Cardiovasc Res 65:148-157

11. Buonanno C, Arbustini E, Rossi L, Dander B, Vassanelli C, Paris B, Poppi A (1982) Left ventricular function in men and women. Another difference between sexes. Eur Heart J 3:525-528

12. Bupha-Intr T, Laosiripisan J, Wattanapermpool J (2009) Moderate intensity of regular exercise improves cardiac SR Ca2+ uptake activity in ovariectomized rats. J Appl Physiol 107:11051112

13. Bupha-Intr T, Wattanapermpool J (2006) Regulatory role of ovarian sex hormones in calcium uptake activity of cardiac sarcoplasmic reticulum. Am J Physiol Heart Circ Physiol 291:H1101H1108

14. Bupha-Intr T, Wattanapermpool J, Pena JR, Wolska BM, Solaro RJ (2007) Myofilament response to $\mathrm{Ca} 2+$ and $\mathrm{Na}+\mathrm{H}+$ exchanger activity in sex hormone-related protection of cardiac myocytes from deactivation in hypercapnic acidosis. Am J Physiol Regul Integr Comp Physiol 292:R837-R843

15. Burke JH, Goldberger JJ, Ehlert FA, Kruse JT, Parker MA, Kadish AH (1996) Gender differences in heart rate before and after autonomic blockade: evidence against an intrinsic gender effect. Am J Med 100:537-543

16. Cannell MB, Cheng H, Lederer WJ (1995) The control of calcium release in heart muscle. Science 268:1045-1049

17. Chase A, Colyer J, Orchard CH (2010) Localised Ca channel phosphorylation modulates the distribution of L-type Ca current in cardiac myocytes. J Mol Cell Cardiol 49:121-131

18. Chen G, Yang X, Alber S, Shusterman V, Salama G (2011) Regional genomic regulation of cardiac sodium-calcium exchanger by oestrogen. J Physiol 589:1061-1080

19. Chen J, Petranka J, Yamamura K, London RE, Steenbergen C, Murphy E (2003) Gender differences in sarcoplasmic reticulum calcium loading after isoproterenol. Am J Physiol Heart Circ Physiol 285:H2657-H2662

20. Cheng H, Lederer WJ, Cannell MB (1993) Calcium sparks: elementary events underlying excitation-contraction coupling in heart muscle. Science 262:740-744

21. Cheng J, Ma X, Zhang J, Su D (2012) Diverse modulating effects of estradiol and progesterone on the monophasic action potential duration in Langendorff-perfused female rabbit hearts. Fundam Clin Pharmacol 26:219-226

22. Chu SH, Goldspink P, Kowalski J, Beck J, Schwertz DW (2006) Effect of estrogen on calcium-handling proteins, beta-adrenergic receptors, and function in rat heart. Life Sci 79:1257-1267

23. Chu SH, Sutherland K, Beck J, Kowalski J, Goldspink P, Schwertz D (2005) Sex differences in expression of calcium- 
handling proteins and beta-adrenergic receptors in rat heart ventricle. Life Sci 76:2735-2749

24. Chung MT, Cheng PY, Lam KK, Chen SY, Ting YF, Yen MH, Lee YM (2010) Cardioprotective effects of long-term treatment with raloxifene, a selective estrogen receptor modulator, on myocardial ischemia/reperfusion injury in ovariectomized rats. Menopause 17:127-134

25. Clark RB, Bouchard RA, Giles WR (1996) Action potential duration modulates calcium influx, $\mathrm{Na}(+)-\mathrm{Ca} 2+$ exchange, and intracellular calcium release in rat ventricular myocytes. Ann N Y Acad Sci 779:417-429

26. Curl CL, Delbridge LM, Canny BJ, Wendt IR (2009) Testosterone modulates cardiomyocyte $\mathrm{Ca}(2+)$ handling and contractile function. Physiol Res 58:293-297

27. Curl CL, Delbridge LM, Wendt IR (2008) Sex differences in cardiac muscle responsiveness to $\mathrm{Ca} 2+$ and L-type $\mathrm{Ca} 2+$ channel modulation. Eur J Pharmacol 586:288-292

28. Curl CL, Wendt IR, Canny BJ, Kotsanas G (2003) Effects of ovariectomy and 17 beta-oestradiol replacement on [Ca2+]i in female rat cardiac myocytes. Clin Exp Pharmacol Physiol 30:489-494

29. Curl CL, Wendt IR, Kotsanas G (2001) Effects of gender on intracellular calcium in rat cardiac myocytes. Pflugers Arch 441:709-716

30. Czubryt MP, Espira L, Lamoureux L, Abrenica B (2006) The role of sex in cardiac function and disease. Can J Physiol Pharmacol 84:93-109

31. de Simone G, Devereux RB, Roman MJ, Ganau A, Chien S, Alderman MH, Atlas S, Laragh JH (1991) Gender differences in left ventricular anatomy, blood viscosity and volume regulatory hormones in normal adults. Am J Cardiol 68:1704-1708

32. Devereux RB, Lutas EM, Casale PN, Kligfield P, Eisenberg RR, Hammond IW, Miller DH, Reis G, Alderman MH, Laragh JH (1984) Standardization of M-mode echocardiographic left ventricular anatomic measurements. J Am Coll Cardiol 4:1222-1230

33. Dibb KM, Eisner DA, Trafford AW (2007) Regulation of systolic $[\mathrm{Ca} 2+] \mathrm{i}$ and cellular $\mathrm{Ca} 2+$ flux balance in rat ventricular myocytes by SR Ca2+, L-type Ca2+ current and diastolic $[\mathrm{Ca} 2+]$ i. J Physiol 585:579-592

34. El-Mas MM, Abdel-Rahman AA (2009) Longitudinal assessment of the effects of oestrogen on blood pressure and cardiovascular autonomic activity in female rats. Clin Exp Pharmacol Physiol 36:1002-1009

35. Endoh M (2006) Signal transduction and Ca2+ signaling in intact myocardium. J Pharmacol Sci 100:525-537

36. Er F, Michels G, Brandt MC, Khan I, Haase H, Eicks M, Lindner M, Hoppe UC (2007) Impact of testosterone on cardiac L-type calcium channels and $\mathrm{Ca} 2+$ sparks: acute actions antagonize chronic effects. Cell Calcium 41:467-477

37. Fabiato A (1985) Simulated calcium current can both cause calcium loading in and trigger calcium release from the sarcoplasmic reticulum of a skinned canine cardiac Purkinje cell. J Gen Physiol 85:291-320

38. Fabiato A (1985) Time and calcium dependence of activation and inactivation of calcium-induced release of calcium from the sarcoplasmic reticulum of a skinned canine cardiac Purkinje cell. J Gen Physiol 85:247-289

39. Fares E, Parks RJ, Macdonald JK, Egar JM, Howlett SE (2012) Ovariectomy enhances SR $\mathrm{Ca}(2)(+)$ release and increases $\mathrm{Ca}(2)(+)$ spark amplitudes in isolated ventricular myocytes. J Mol Cell Cardiol 52:32-42

40. Farrell SR, Ross JL, Howlett SE (2010) Sex differences in mechanisms of cardiac excitation-contraction coupling in rat ventricular myocytes. Am J Physiol Heart Circ Physiol 299:H36-H45

41. Ferrier GR, Smith RH, Howlett SE (2003) Calcium sparks in mouse ventricular myocytes at physiological temperature. Am J Physiol Heart Circ Physiol 285:H1495-H1505
42. Ginsburg KS, Bers DM (2004) Modulation of excitation-contraction coupling by isoproterenol in cardiomyocytes with controlled SR $\mathrm{Ca} 2+$ load and $\mathrm{Ca} 2+$ current trigger. J Physiol 556:463-480

43. Golden KL, Marsh JD, Jiang Y, Brown T, Moulden J (2003) Gonadectomy of adult male rats reduces contractility of isolated cardiac myocytes. Am J Physiol Endocrinol Metab 285:E449 E453

44. Golden KL, Marsh JD, Jiang Y, Moulden J (2005) Acute actions of testosterone on contractile function of isolated rat ventricular myocytes. Eur J Endocrinol 152:479-483

45. Goldstein J, Sites CK, Toth MJ (2004) Progesterone stimulates cardiac muscle protein synthesis via receptor-dependent pathway. Fertil Steril 82:430-436

46. Grandy SA, Howlett SE (2006) Cardiac excitation-contraction coupling is altered in myocytes from aged male mice but not in cells from aged female mice. Am J Physiol Heart Circ Physiol 291:H2362-H2370

47. Grohe C, Kahlert S, Lobbert K, Stimpel M, Karas RH, Vetter H, Neyses L (1997) Cardiac myocytes and fibroblasts contain functional estrogen receptors. FEBS Lett 416:107-112

48. Grohe C, Kahlert S, Lobbert K, Vetter H (1998) Expression of oestrogen receptor alpha and beta in rat heart: role of local oestrogen synthesis. J Endocrinol 156:R1-R7

49. Guatimosim S, Dilly K, Santana LF, Saleet Jafri M, Sobie EA, Lederer WJ (2002) Local $\mathrm{Ca}(2+)$ signaling and $\mathrm{EC}$ coupling in heart: $\mathrm{Ca}(2+)$ sparks and the regulation of the $[\mathrm{Ca}(2+)](\mathrm{i})$ transient. J Mol Cell Cardiol 34:941-950

50. Guo T, Zhang T, Mestril R, Bers DM (2006) Ca2+/Calmodulindependent protein kinase II phosphorylation of ryanodine receptor does affect calcium sparks in mouse ventricular myocytes. Circ Res 99:398-406

51. Handelsman D, Simanainen U, Walters K, Allan C (2012) Estradiol immunoassays for mice: not fit for purpose. Endocrinology

52. Hanley PC, Zinsmeister AR, Clements IP, Bove AA, Brown ML, Gibbons RJ (1989) Gender-related differences in cardiac response to supine exercise assessed by radionuclide angiography. J Am Coll Cardiol 13:624-629

53. Harman SM (2006) Estrogen replacement in menopausal women: recent and current prospective studies, the WHI and the KEEPS. Gend Med 3:254-269

54. Hayward CS, Kelly RP, Collins P (2000) The roles of gender, the menopause and hormone replacement on cardiovascular function. Cardiovasc Res 46:28-49

55. Howlett SE (2010) Age-associated changes in excitationcontraction coupling are more prominent in ventricular myocytes from male rats than in myocytes from female rats. Am J Physiol Heart Circ Physiol 298:H659-H670

56. James AF, Arberry LA, Hancox JC (2004) Gender-related differences in ventricular myocyte repolarization in the guinea pig. Basic Res Cardiol 99:183-192

57. Jiang C, Poole-Wilson PA, Sarrel PM, Mochizuki S, Collins P, MacLeod KT (1992) Effect of 17 beta-oestradiol on contraction, $\mathrm{Ca} 2+$ current and intracellular free $\mathrm{Ca} 2+$ in guinea-pig isolated cardiac myocytes. Br J Pharmacol 106:739-745

58. Kam KW, Kravtsov GM, Liu J, Wong TM (2005) Increased PKA activity and its influence on isoprenaline-stimulated L-type Ca2+ channels in the heart from ovariectomized rats. Br J Pharmacol 144:972-981

59. Kameyama M, Hescheler J, Hofmann F, Trautwein W (1986) Modulation of $\mathrm{Ca}$ current during the phosphorylation cycle in the guinea pig heart. Pflugers Arch 407:123-128

60. Kaneko K, Aoki H, Furuichi T, Hatori S, Tanimoto H, Kawakami $\mathrm{S}$ (2004) Influence of uterine inflammation on the estrous cycle in rats. J Reprod Dev 50:361-367

61. Kaushik M, Sontineni SP, Hunter C (2010) Cardiovascular disease and androgens: a review. Int J Cardiol 142:8-14 
62. Korzick DH (2003) Regulation of cardiac excitation-contraction coupling: a cellular update. Adv Physiol Educ 27:192-200

63. Kravtsov GM, Kam KW, Liu J, Wu S, Wong TM (2007) Altered $\mathrm{Ca}(2+)$ handling by ryanodine receptor and $\mathrm{Na}(+)-\mathrm{Ca}(2+)$ exchange in the heart from ovariectomized rats: role of protein kinase A. Am J Physiol Cell Physiol 292:C1625-C1635

64. Kulpa J, Chinnappareddy N, Pyle WG (2012) Rapid changes in cardiac myofilament function following the acute activation of estrogen receptor-alpha. PLoS One 7:e41076

65. Leblanc N, Chartier D, Gosselin H, Rouleau JL (1998) Age and gender differences in excitation-contraction coupling of the rat ventricle. J Physiol 511(Pt 2):533-548

66. Li HY, Bian JS, Kwan YW, Wong TM (2000) Enhanced responses to 17 beta-estradiol in rat hearts treated with isoproterenol: involvement of a cyclic AMP-dependent pathway. J Pharmacol Exp Ther 293:592-598

67. Li L, Desantiago J, Chu G, Kranias EG, Bers DM (2000) Phosphorylation of phospholamban and troponin I in betaadrenergic-induced acceleration of cardiac relaxation. Am J Physiol Heart Circ Physiol 278:H769-H779

68. Lim CC, Apstein CS, Colucci WS, Liao R (2000) Impaired cell shortening and relengthening with increased pacing frequency are intrinsic to the senescent mouse cardiomyocyte. J Mol Cell Cardiol 32:2075-2082

69. Luczak ED, Leinwand LA (2009) Sex-based cardiac physiology. Annu Rev Physiol 71:1-18

70. Ma Y, Cheng WT, Wu S, Wong TM (2009) Oestrogen confers cardioprotection by suppressing $\mathrm{Ca} 2+/$ calmodulin-dependent protein kinase II. Br J Pharmacol 157:705-715

71. Marsh JD (2010) Turning cardiac excitation into cell contraction: the importance of sex differences. Am J Physiol Heart Circ Physiol 299:H16-H17

72. Marsh JD, Lehmann MH, Ritchie RH, Gwathmey JK, Green GE, Schiebinger RJ (1998) Androgen receptors mediate hypertrophy in cardiac myocytes. Circulation 98:256-261

73. Mason SA, MacLeod KT (2009) Cardiac action potential duration and calcium regulation in males and females. Biochem Biophys Res Commun 388:565-570

74. McClintock M (1983) Pheromonal regulation of the ovarian cycle: enhancement, suppression and synchrony. In: Vandenbergh JG (ed) Pheromones and reproduction in mammals. Academic, New York

75. McNamara KM, Harwood DT, Simanainen U, Walters KA, Jimenez M, Handelsman DJ (2010) Measurement of sex steroids in murine blood and reproductive tissues by liquid chromatography-tandem mass spectrometry. J Steroid Biochem Mol Biol 121:611-618

76. Merz CN, Moriel M, Rozanski A, Klein J, Berman DS (1996) Gender-related differences in exercise ventricular function among healthy subjects and patients. Am Heart J 131:704-709

77. Meyer R, Linz KW, Surges R, Meinardus S, Vees J, Hoffmann A, Windholz O, Grohe C (1998) Rapid modulation of L-type calcium current by acutely applied oestrogens in isolated cardiac myocytes from human, guinea-pig and rat. Exp Physiol 83:305321

78. Miller VM, Black DM, Brinton EA, Budoff MJ, Cedars MI, Hodis HN, Lobo RA, Manson JE, Merriam GR, Naftolin F, Santoro N, Taylor HS, Harman SM (2009) Using basic science to design a clinical trial: baseline characteristics of women enrolled in the Kronos Early Estrogen Prevention Study (KEEPS). J Cardiovasc Transl Res 2:228-239

79. Murphy E (2011) Estrogen signaling and cardiovascular disease. Circ Res 109:687-696

80. Nakamura H, Kurokawa J, Bai CX, Asada K, Xu J, Oren RV, Zhu ZI, Clancy CE, Isobe M, Furukawa T (2007) Progesterone regulates cardiac repolarization through a nongenomic pathway: an in vitro patch-clamp and computational modeling study. Circulation 116:2913-2922

81. Parks RJ, Howlett SE (2012) H-89 decreases the gain of excitation-contraction coupling and attenuates calcium sparks in the absence of beta-adrenergic stimulation. Eur J Pharmacol 691:163-172

82. Peters RW, Gold MR (2004) The influence of gender on arrhythmias. Cardiol Rev 12:97-105

83. Petre RE, Quaile MP, Rossman EI, Ratcliffe SJ, Bailey BA, Houser SR, Margulies KB (2007) Sex-based differences in myocardial contractile reserve. Am J Physiol Regul Integr Comp Physiol 292:R810-R818

84. Pilote L, Dasgupta K, Guru V, Humphries KH, McGrath J, Norris C, Rabi D, Tremblay J, Alamian A, Barnett T, Cox J, Ghali WA, Grace S, Hamet P, Ho T, Kirkland S, Lambert M, Libersan D, O'Loughlin J, Paradis G, Petrovich M, Tagalakis V (2007) A comprehensive view of sex-specific issues related to cardiovascular disease. CMAJ 176:S1-S44

85. Price T, Aitken J, Simpson ER (1992) Relative expression of aromatase cytochrome $\mathrm{P} 450$ in human fetal tissues as determined by competitive polymerase chain reaction amplification. J Clin Endocrinol Metab 74:879-883

86. Puglisi JL, Bassani RA, Bassani JW, Amin JN, Bers DM (1996) Temperature and relative contributions of $\mathrm{Ca}$ transport systems in cardiac myocyte relaxation. Am J Physiol 270:H1772-H1778

87. Regitz-Zagrosek V, Seeland U (2012) Sex and gender differences in clinical medicine. Handb Exp Pharmacol 214:3-22

88. Ren J, Hintz KK, Roughead ZK, Duan J, Colligan PB, Ren BH, Lee KJ, Zeng H (2003) Impact of estrogen replacement on ventricular myocyte contractile function and protein kinase B/Akt activation. Am J Physiol Heart Circ Physiol 284:H1800-H1807

89. Reuter H, Pott C, Goldhaber JI, Henderson SA, Philipson KD, Schwinger $\mathrm{RH}(2005) \mathrm{Na}(+)-\mathrm{Ca} 2+$ exchange in the regulation of cardiac excitation-contraction coupling. Cardiovasc Res 67:198-207

90. Roger VL, Go AS, Lloyd-Jones DM, Adams RJ, Berry JD, Brown TM, Carnethon MR, Dai S, de Simone G, Ford ES, Fox CS, Fullerton HJ, Gillespie C, Greenlund KJ, Hailpern SM, Heit JA, Ho PM, Howard VJ, Kissela BM, Kittner SJ, Lackland DT, Lichtman JH, Lisabeth LD, Makuc DM, Marcus GM, Marelli A, Matchar DB, McDermott MM, Meigs JB, Moy CS, Mozaffarian D, Mussolino ME, Nichol G, Paynter NP, Rosamond WD, Sorlie PD, Stafford RS, Turan TN, Turner MB, Wong ND, Wylie-Rosett J (2011) Heart disease and stroke statistics-2011 update: a report from the American Heart Association. Circulation 123:e18-e209

91. Ropero AB, Eghbali M, Minosyan TY, Tang G, Toro L, Stefani E (2006) Heart estrogen receptor alpha: distinct membrane and nuclear distribution patterns and regulation by estrogen. $\mathrm{J}$ Mol Cell Cardiol 41:496-510

92. Rosenkranz-Weiss P, Tomek RJ, Mathew J, Eghbali M (1994) Gender-specific differences in expression of mRNAs for functional and structural proteins in rat ventricular myocardium. $\mathrm{J} \mathrm{Mol}$ Cell Cardiol 26:261-270

93. Saito T, Ciobotaru A, Bopassa JC, Toro L, Stefani E, Eghbali M (2009) Estrogen contributes to gender differences in mouse ventricular repolarization. Circ Res 105:343-352

94. Satoh H, Blatter LA, Bers DM (1997) Effects of [Ca2+]i, SR $\mathrm{Ca} 2+$ load, and rest on $\mathrm{Ca} 2+$ spark frequency in ventricular myocytes. Am J Physiol 272:H657-H668

95. Schaible TF, Scheuer J (1984) Comparison of heart function in male and female rats. Basic Res Cardiol 79:402-412

96. Schwertz DW, Beck JM, Kowalski JM, Ross JD (2004) Sex differences in the response of rat heart ventricle to calcium. Biol Res Nurs 5:286-298

97. Scriven DR, Dan P, Moore ED (2000) Distribution of proteins implicated in excitation-contraction coupling in rat ventricular myocytes. Biophys J 79:2682-2691 
98. Sharp P, LaRegina M, Suckow M (1998) The laboratory rat. CRC Press, Boca Raton

99. Shutt RH, Ferrier GR, Howlett SE (2006) Increases in diastolic $[\mathrm{Ca} 2+]$ can contribute to positive inotropy in guinea pig ventricular myocytes in the absence of changes in amplitudes of $\mathrm{Ca} 2+$ transients. Am J Physiol Heart Circ Physiol 291:H1623-H1634

100. Shutt RH, Howlett SE (2008) Hypothermia increases the gain of excitation-contraction coupling in guinea pig ventricular myocytes. Am J Physiol Cell Physiol 295:C692-C700

101. Simpson ER (2003) Sources of estrogen and their importance. J Steroid Biochem Mol Biol 86:225-230

102. Sims C, Reisenweber S, Viswanathan PC, Choi BR, Walker WH, Salama G (2008) Sex, age, and regional differences in L-type calcium current are important determinants of arrhythmia phenotype in rabbit hearts with drug-induced long QT type 2. Circ Res 102:e86-e100

103. Sipido KR (2006) Calcium overload, spontaneous calcium release, and ventricular arrhythmias. Hear Rhythm 3:977-979

104. Stypmann J, Engelen MA, Epping C, van Rijen HV, Milberg P, Bruch C, Breithardt G, Tiemann K, Eckardt L (2006) Age and gender related reference values for transthoracic Dopplerechocardiography in the anesthetized CD1 mouse. Int $\mathrm{J}$ Cardiovasc Imaging 22:353-362

105. Tanabe S, Hata T, Hiraoka M (1999) Effects of estrogen on action potential and membrane currents in guinea pig ventricular myocytes. Am J Physiol 277:H826-H833

106. Tappia PS, Dent MR, Aroutiounova N, Babick AP, Weiler H (2007) Gender differences in the modulation of cardiac gene expression by dietary conjugated linoleic acid isomers. Can J Physiol Pharmacol 85:465-475

107. Teplitz L, Igic R, Berbaum ML, Schwertz DW (2005) Sex differences in susceptibility to epinephrine-induced arrhythmias. J Cardiovasc Pharmacol 46:548-555

108. Thawornkaiwong A, Preawnim S, Wattanapermpool J (2003) Upregulation of beta 1-adrenergic receptors in ovariectomized rat hearts. Life Sci 72:1813-1824

109. Trepanier-Boulay V, St-Michel C, Tremblay A, Fiset C (2001) Gender-based differences in cardiac repolarization in mouse ventricle. Circ Res 89:437-444

110. Ullrich ND, Krust A, Collins P, MacLeod KT (2008) Genomic deletion of estrogen receptors ERalpha and ERbeta does not alter estrogen-mediated inhibition of $\mathrm{Ca} 2+$ influx and contraction in murine cardiomyocytes. Am J Physiol Heart Circ Physiol 294: $\mathrm{H} 2421-\mathrm{H} 2427$

111. Vasan RS, Larson MG, Levy D, Evans JC, Benjamin EJ (1997) Distribution and categorization of echocardiographic measurements in relation to reference limits: the Framingham Heart Study: formulation of a height- and sex-specific classification and its prospective validation. Circulation 96:1863-1873

112. Viatchenko-Karpinski S, Gyorke S (2001) Modulation of the $\mathrm{Ca}(2+)$-induced $\mathrm{Ca}(2+)$ release cascade by beta-adrenergic stimulation in rat ventricular myocytes. J Physiol 533:837-848
113. Vizgirda VM, Wahler GM, Sondgeroth KL, Ziolo MT, Schwertz DW (2002) Mechanisms of sex differences in rat cardiac myocyte response to beta-adrenergic stimulation. Am J Physiol Heart Circ Physiol 282:H256-H263

114. Wasserstrom JA, Kapur S, Jones S, Faruque T, Sharma R, Kelly JE, Pappas A, Ho W, Kadish AH, Aistrup GL (2008) Characteristics of intracellular $\mathrm{Ca} 2+$ cycling in intact rat heart: a comparison of sex differences. Am J Physiol Heart Circ Physiol 295:H1895-H1904

115. Wattanapermpool J, Reiser PJ (1999) Differential effects of ovariectomy on calcium activation of cardiac and soleus myofilaments. Am J Physiol 277:H467-H473

116. Wattanapermpool J, Riabroy T, Preawnim S (2000) Estrogen supplement prevents the calcium hypersensitivity of cardiac myofilaments in ovariectomized rats. Life Sci 66:533-543

117. Wei SK, McCurley JM, Hanlon SU, Haigney MC (2007) Gender differences in $\mathrm{Na} / \mathrm{Ca}$ exchanger current and beta-adrenergic responsiveness in heart failure in pig myocytes. Ann N Y Acad Sci 1099:183-189

118. Whitten W (1966) Pheromones and mammalian reproduction. In: Mclaren A (ed) Advances in reproductive physiology. Academic, New York

119. Whitten WK (1959) Occurrence of anoestrus in mice caged in groups. J Endocrinol 18:102-107

120. Witayavanitkul N, Woranush W, Bupha-Intr T, Wattanapermpool J (2013) Testosterone regulates cardiac contractile activation by modulating SERCA but not NCX activity. Am J Physiol Heart Circ Physiol 304(3):H465-H472

121. Wood GA, Fata JE, Watson KL, Khokha R (2007) Circulating hormones and estrous stage predict cellular and stromal remodeling in murine uterus. Reproduction 133:1035-1044

122. Wu Q, Zhao Z, Sun H, Hao YL, Yan CD, Gu SL (2008) Oestrogen changed cardiomyocyte contraction and betaadrenoceptor expression in rat hearts subjected to ischaemiareperfusion. Exp Physiol 93:1034-1043

123. Xiao L, Zhang L, Han W, Wang Z, Nattel S (2006) Sex-based transmural differences in cardiac repolarization and ionic-current properties in canine left ventricles. Am J Physiol Heart Circ Physiol 291:H570-H580

124. Yaras N, Tuncay E, Purali N, Sahinoglu B, Vassort G, Turan B (2007) Sex-related effects on diabetes-induced alterations in calcium release in the rat heart. Am J Physiol Heart Circ Physiol 293:H3584-H3592

125. Yarnoz MJ, Curtis AB (2008) More reasons why men and women are not the same (gender differences in electrophysiology and arrhythmias). Am J Cardiol 101:1291-1296

126. Zalk R, Lehnart SE, Marks AR (2007) Modulation of the ryanodine receptor and intracellular calcium. Annu Rev Biochem $76: 367-385$

127. Zhang R, Zhao J, Mandveno A, Potter JD (1995) Cardiac troponin I phosphorylation increases the rate of cardiac muscle relaxation. Circ Res 76:1028-1035 